\title{
Physical inactivity, gender and culture in Arab countries: a systematic assessment of the literature
}

\author{
Eman Sharara', Chaza Akik ${ }^{1 *}$, Hala Ghattas ${ }^{1}$ and Carla Makhlouf Obermeyer ${ }^{1,2}$
}

\begin{abstract}
Background: Physical inactivity is associated with excess weight and adverse health outcomes. We synthesize the evidence on physical inactivity and its social determinants in Arab countries, with special attention to gender and cultural context.

Methods: We searched MEDLINE, Popline, and SSCI for articles published between 2000 and 2016, assessing the prevalence of physical inactivity and its social determinants. We also included national survey reports on physical activity, and searched for analyses of the social context of physical activity.

Results: We found 172 articles meeting inclusion criteria. Standardized data are available from surveys by the World Health Organization for almost all countries, but journal articles show great variability in definitions, measurements and methodology. Prevalence of inactivity among adults and children/adolescents is high across countries, and is higher among women. Some determinants of physical inactivity in the region (age, gender, low education) are shared with other regions, but specific aspects of the cultural context of the region seem particularly discouraging of physical activity. We draw on social science studies to gain insights into why this is so.

Conclusions: Physical inactivity among Arab adults and children/adolescents is high. Studies using harmonized approaches, rigorous analytic techniques and a deeper examination of context are needed to design appropriate interventions.
\end{abstract}

Keywords: Physical activity, Social determinants, Gender, Culture, Arab countries

\section{Background}

Global increases in body mass index, raised blood pressure and cardiovascular disease have been attributed in part to the reduction in physical activity resulting from changes in the organization of labor and transportation, and to increases in sedentary behavior. The evidence on the magnitude of these changes and their consequences for health is well recognized. The World Health Organization (WHO) ranks physical inactivity as the fourth leading cause of global mortality, estimating that it results in 3.2 million deaths globally, mainly due to cardiovascular disease, diabetes, hypertension, and some cancers [1-6]. Analyses of the Global Burden of Disease estimate that

\footnotetext{
* Correspondence: ca36@aub.edu.lb

${ }^{1}$ Center for Research on Population and Health, Faculty of Health Sciences, American University of Beirut, P.O. Box 11-0236/EPHD, Riad El Solh, Beirut, Lebanon

Full list of author information is available at the end of the article
}

insufficient physical activity accounts for an estimated 13.4 million disability adjusted life years (DALYs) related to ischemic heart disease, diabetes and stroke [7].

There are major variations in the prevalence of physical inactivity across regions and among countries. In the Arab region, alarming predictions have been made in light of very unfavorable combinations of risk factors related to body mass index, its determinants including physical activity, and its health consequences [8-10]. Some studies have compared indicators across countries [11-15], but there have not been comprehensive assessments of the prevalence and determinants of physical inactivity across the Arab region. Yet, such regionally specific assessments are key to identify patterns and formulate interventions, and would be especially timely, given mounting evidence on the health effects of sedentary behaviour and physical inactivity, the growing awareness of the need

(c) The Author(s). 2018 Open Access This article is distributed under the terms of the Creative Commons Attribution 4.0 International License (http://creativecommons.org/licenses/by/4.0/), which permits unrestricted use, distribution, and 
for population interventions, and the urgency of scaling up policies and programs to increase physical activity in low and middle income countries [16]. In addition, there is a need to go beyond simplistic explanations of observed patterns in terms of religion or education.

Hence, this study was designed to review research on the subject, assess levels and variability in physical inactivity across countries and social groups, and gain insights into the extent to which social determinants, in particular those related to gender, could explain such unfavorable indicators. The diversity of indicators and measures in the region, and the difficulty of obtaining original survey data precluded the possibility of conducting a systematic review or meta-analysis. But we thought it was important to take stock of what was known about physical inactivity in the region and to review the explanations that are offered for observed levels, in order to identify patterns and to inform policies designed to increase physical activity.

The review proceeds as follows. We first present a summary of the evidence from studies published in peerreviewed journals, including the availability and comparability of studies and the instruments used. Secondly, we provide a synthesis of prevalence levels based on the reports of surveys that have used standardized definitions and measurements. We then bring together the results of studies that examined the social determinants of physical activity, with special attention to those related to gender and cultural factors. Lastly we draw the implications of these results for research and policies.

\section{Methods}

\section{Search strategy and inclusion criteria}

We sought to retrieve research published in refereed journals and reports of surveys, and our approach was threepronged. First, we searched for articles in refereed journals investigating physical inactivity in countries of the Arab region, published between January 2000 and January 2016, in MEDLINE, Popline and Social Sciences Citation Index (SSCI) databases. Various combinations of $\mathrm{MeSH}$ terms and key words were used, related to physical activity/ inactivity, sedentary lifestyle, exercise, sports, its prevalence, incidence, epidemiology, the burden it represents, and social or cultural factors. Details are shown in Additional file 1 . Studies published in any language were retrieved. Two researchers conducted title and abstract screening, followed by full-text screening, checking to harmonize results regarding inclusion or exclusion; disagreements were discussed by the team as a whole and resolved. This was done according to the Assessing the Methodological Quality of Systematic Reviews (AMSTAR) appraisal tool for systematic reviews [17]. In addition to the electronic search, we searched reference lists of the articles identified.

Sources were included if they fulfilled the following criteria: assessed physical activity or inactivity as an outcome or a determinant; were conducted among residents of Arab countries (the 22 countries of the Arab League: Algeria, Bahrain, Comoros, Djibouti, Egypt, Iraq, Jordan, Kingdom of Saudi Arabia (KSA), Kuwait, Lebanon, Libya, Mauritania, Morocco, Oman, Palestine, Qatar, Somalia, Sudan, Syria, Tunisia, United Arab Emirates (UAE), and Yemen); described the design and methods; reported on sample size; described how physical activity/inactivity was measured; reported on the prevalence of physical activity/ inactivity. Multi-country studies were included if they presented data on at least one Arab country. Studies conducted exclusively on patients with a particular disease diagnosis, and studies conducted on Arabs residing outside the Arab region were excluded. To be included, articles needed to fulfill quality criteria informed by the Preferred Reporting Items for Systematic Reviews and Meta-Analyses (PRISMA) guidelines [18], including clear eligibility criteria for study selection, description of information sources, data and variables; we excluded studies that did not report on sample size, age range of study population, and those that presented unclear or inconsistent numbers.

Secondly, we retrieved the reports of surveys on physical activity conducted by international organizations in collaboration with country partners; these surveys generally use standardized instruments and the two main sources are the World Health Organization (WHO) surveys on non-communicable disease risk factors (STEPS) which include modules on physical activity among adults; and the Global School-based Student Health Surveys (GSHS) which measure activity among adolescents. We present results separately for studies based on national surveys using standardized definitions and measures, and whose results represent comparable and higher-quality estimates.

A third part of the review was to retrieve data from sources that considered physical inactivity in relation to social factors such as age, marriage, education, employment, residence, and those that examined cultural and social barriers to physical activity. We sought to gain insights into the socio-cultural context of physical activity, and to explain the patterns that emerged from the analysis of the quantifiable data. We extracted notes and themes from those sources that included qualitative information, and provide a critical synthesis of main findings. Thus, this review draws both on rigorous quantitative analyses and a narrative synthesis of qualitative studies.

\section{Data extraction and analysis}

Citations from search results of databases were imported into the reference manager EndNote and duplicates removed. We used the open-source Open Data Kit (ODK) (https://ona.io/) to create the data entry protocol. The data extracted for each study included: (1) article identification (title, author/s, publication year, journal, country/ 
ies of study); (2) research design, setting, sample size, study population, gender, and age; (3) definition of physical activity/inactivity, instrument used, reported prevalence; and, (4) demographic, economic, lifestyle and social correlates of physical inactivity. In addition, we retrieved themes from those studies that examined the social context of physical activity and provided information about gender and cultural differences.

We retrieved the most recent data from STEPS and GSHS surveys. For countries where no published reports were available, we retrieved any data available from the WHO website.

Regarding the outcome variable, because of the diversity of definitions and measures of physical activity, we found that the most consistent way to report the results was to use physical inactivity, which refers to not engaging in any physical activity and/or being in the lowest category of physical activity, however physical activity was defined in the study. This is consistent with other studies that have reviewed physical activity across the world [13].

We present results separately for adults and for children/adolescents. We defined as adults those respondents aged 18 or older, or those who were categorized as adults in the articles; younger respondents were categorized as children/adolescents. In the discussion, we build on the narrative synthesis of qualitative studies.

\section{Results}

\section{The evidence on physical inactivity}

\section{Sources and quality of data}

Our search retrieved 1,228 articles, of which 172 met the inclusion criteria. Figure 1 provides a flow chart of the review's inclusion and exclusion process. The included articles referred to a total of 157 datasets: 149 from studies conducted in a single country and 8 conducted as part of multi-country studies; the results of multi-country studies are counted once for each individual country. Some articles were based on the same datasets, including six articles based on STEPS and GSHS surveys. Only 16/143 journal articles reported on surveys using nationally representative samples; qualitative data were retrieved from five qualitative studies and from four mixed methods studies.

All STEPS and GSHS, and 125/157 journal articles include both men/boys and women/girls. GSHS surveys (usually on adolescents 13-15) have been conducted in all but four countries of the region (Bahrain, Comoros, KSA, and Somalia). STEPS surveys usually include adults aged 25-64. Age categories in journal articles are more diverse. 12 countries had both STEPS and GSHS surveys. Unlike GSHS, not all STEPS were based on nationally representative samples (exceptions were Algeria, Mauritania, Oman and Sudan). Additional results about the prevalence of physical inactivity and its determinants are available from journal articles that used the World Health Surveys (WHS) as data sources. STEPS are based on household surveys and GSHS on school populations, while the settings in journal articles included schools (28\%), health facilities (27\%), households (16\%), and universities (15\%).

Table 1 shows disparities in the available evidence: for some countries there are very few studies (Algeria, Comoros, Djibouti, Iraq, Somalia, Sudan and Yemen), while for others many more sources are available (for example 40 for Saudi Arabia). There is also a variability in sample size, with most studies in the range of 200-2000 and a few large studies including several thousand respondents.

STEPS and GSHS use standardized instruments, namely the Global Physical Activity Questionnaire (GPAQ) and the Patient-Centered Assessment and Counseling for Exercise

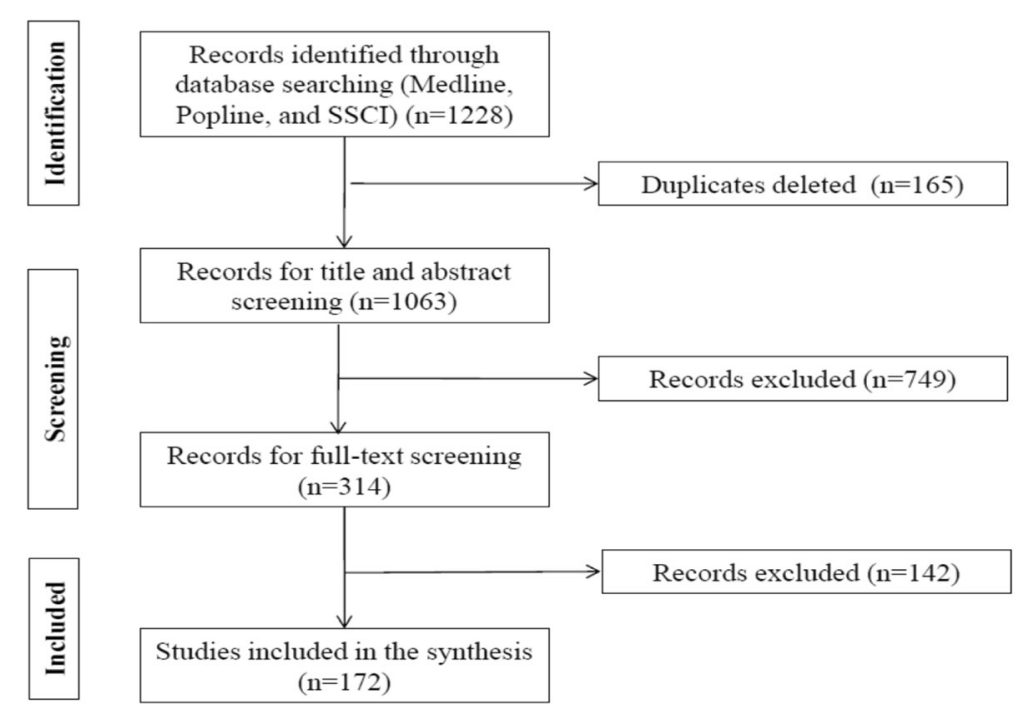

Fig. 1 Flow chart of the review's inclusion and exclusion process 


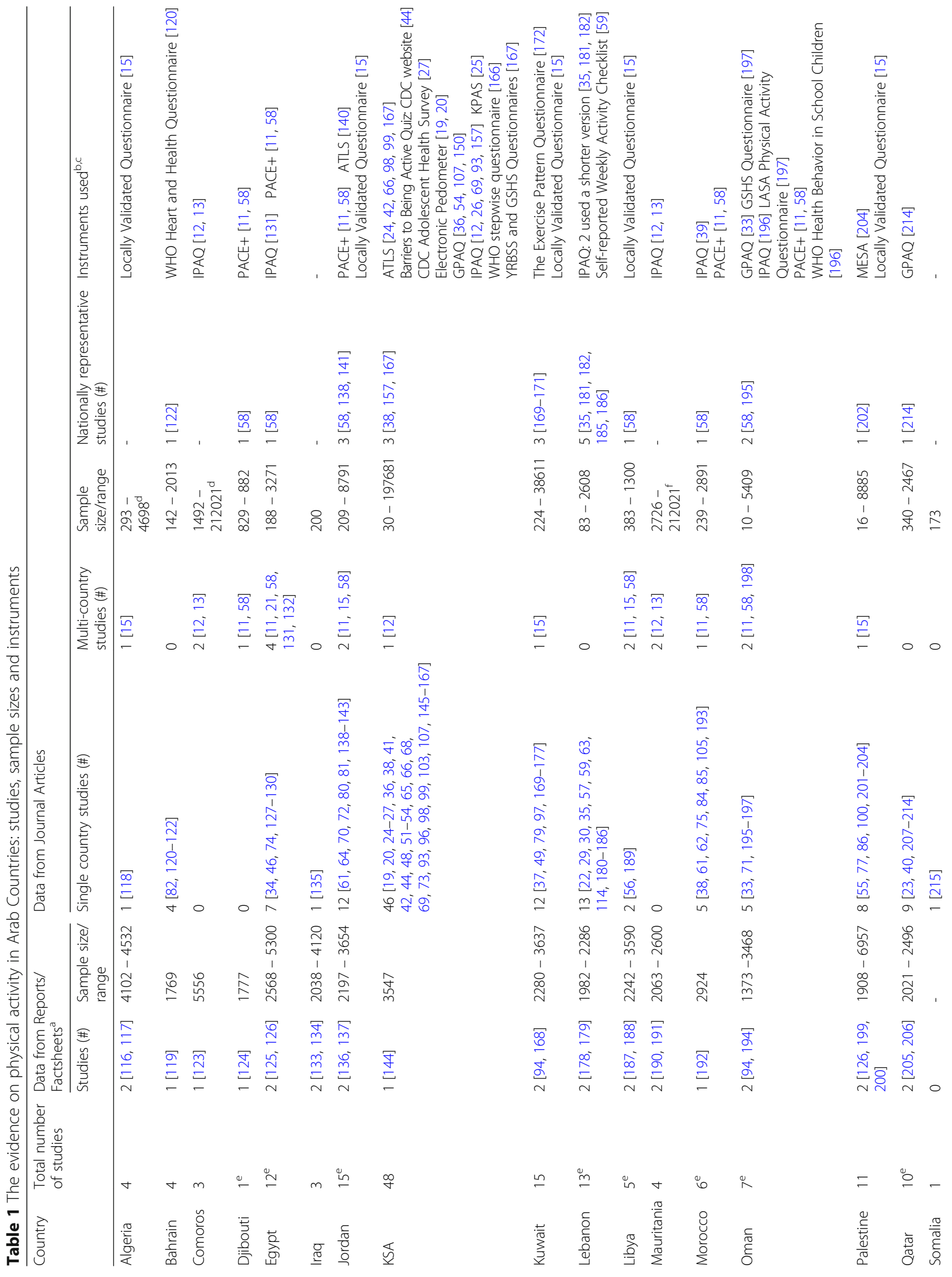




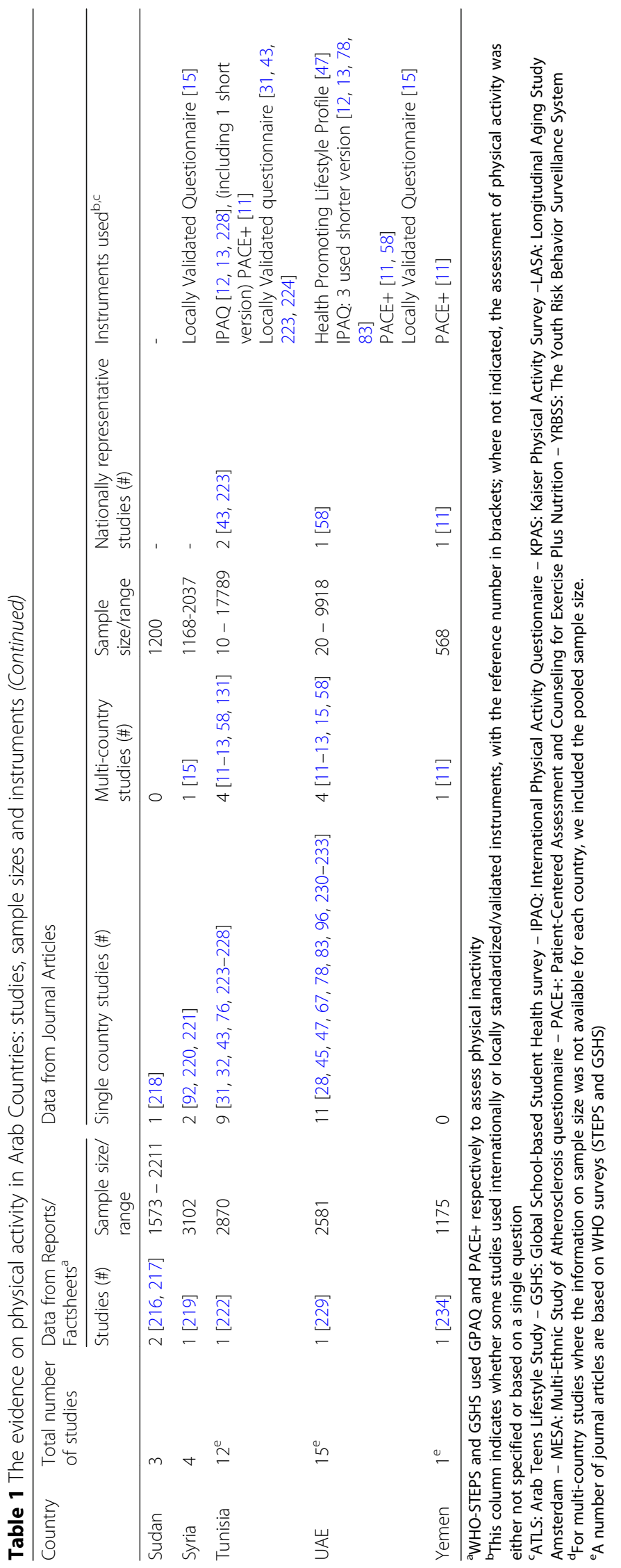


Plus Nutrition (PACE+) respectively, but only 38/143 journal articles referred to studies that used validated instruments. About half of these used internationally validated tools, such as the International Physical Activity Questionnaire (IPAQ), the GPAQ or the PACE+; others used regionally or nationally validated questionnaires. Two studies used electronic pedometers $[19,20]$. The majority of studies $(112 / 157)$ simply used respondents' reports. Only five studies followed the WHO's recommendations regarding the multi-dimensional categorization of physical activity into work, active transportation, household and family, and leisure-time activities; the questionnaires that follow this recommendation include the long version of IPAQ, the GPAQ, and the Kaiser Physical Activity Survey (KPAS).

\section{Prevalence of physical inactivity}

Tables 2 and 3 present the prevalence of physical inactivity among adults; Table 2 summarizes data from WHOSTEPS surveys and Table 3 presents results of journal articles. Among adults, the prevalence of physical inactivity defined as performing less than 600 MET-minute per week, exceeded $40 \%$ in all Arab countries except for Comoros (21\%), Egypt (32\%) Jordan (5\%); it reached $68 \%$ in KSA (national) and $87 \%$ in Sudan (subnational).

Among the 102 journal articles on adults, 48 reported on prevalence among both men and women. In most countries, inactivity exceeded 40\%; a few studies found lower inactivity, including nationally representative studies in Comoros (3\%), Morocco (17\%), and Tunisia (15\%), and subnational studies in Egypt and Somalia (34\%) and Jordan (23\%).

Physical inactivity among children/adolescents is presented in Tables 4 and 5, based on GSHS reports (Table 4) and journal articles (Table 5). Prevalence of physical inactivity, defined in GSHS as $<60$ minutes per day on 5 or more days during the past seven days, is very high, with a low of $65 \%$ in Lebanon and a high of $91 \%$ in Egypt. Journal articles report similarly high levels of inactivity (>60\%) except in KSA (45\%) and Tunisia (29\%), with smaller studies showing a wide variation within and among countries.

\section{Gender differences in physical inactivity}

Where physical activity was reported among men/boys and women/girls, we calculated the $\mathrm{M} / \mathrm{F}$ ratio of the prevalence of physical inactivity. Figures 2 and 3 show gender ratios among adults and children/adolescents respectively. Overall, the prevalence of inactivity was higher among women/girls in all but 9 studies (8 adults and 1 children/adolescents).

\section{Socio-demographic and lifestyle determinants}

Data from 41 articles about sociodemographic determinants of inactivity were analyzed and results are summarized in Table 6. Inactivity increased with age (18/24 studies), being married (7/10 studies), and urban residence (5/5 studies); it decreased with increased education (14/20 studies) and employment (6/8 studies); parity was positively associated with inactivity in one study. For

Table 2 Prevalence of physical inactivity among adults based on data from WHO-STEPS surveys

\begin{tabular}{|c|c|c|c|c|}
\hline Country $^{a}$ & Year of study & Age range & Sample size & Prevalence of Physical inactivity \\
\hline \multicolumn{5}{|l|}{ National samples } \\
\hline Comoros & 2011 & $25-64$ & 5556 & 20.1 \\
\hline Egypt & 2011-2012 & $15-64$ & 5300 & 32.1 \\
\hline Jordan & 2007 & $18+$ & 3654 & 5.2 \\
\hline Iraq & 2015 & $18+$ & 4120 & 47.0 \\
\hline Kuwait & 2014 & $18-69$ & 4391 & 62.6 \\
\hline Libya & 2009 & $25-64$ & 3590 & 43.9 \\
\hline Lebanon & 2008 & $25-64$ & 1982 & 45.8 \\
\hline Palestine & 2010-2011 & $15-64$ & 6957 & 46.5 \\
\hline Qatar & 2012 & $18-64$ & 2496 & 45.9 \\
\hline Saudi Arabia & 2005 & $25-64$ & 3547 & 67.6 \\
\hline \multicolumn{5}{|c|}{ Subnational samples } \\
\hline Algeria & 2003 & $25-64$ & 4102 & 40.7 \\
\hline Mauritania & 2006 & $25-64$ & $1971^{b}$ & 51.3 \\
\hline Sudan & 2005-2006 & $25-64$ & 1573 & 86.8 \\
\hline
\end{tabular}

${ }^{a}$ For Bahrain and Oman, surveys were available but no total physical inactivity prevalence could be retrieved; specific prevalence of work, transportation, and leisure time were $71.9 \%, 63.9 \%$, and $57.1 \%$, respectively for Bahrain and $6.4 \%, 30.1 \%$, and $53.8 \%$ for Oman

bample size was calculated for age group (25-64) from numbers provided in the report 
Table 3 Prevalence of physical inactivity among adults based on findings from published literature

\begin{tabular}{|c|c|c|c|c|c|c|c|}
\hline Country & $\begin{array}{l}\text { First author, year } \\
\text { (year of study) }\end{array}$ & Source & Definition & Instrument & Prevalence (\%) & Age range & $\begin{array}{l}\text { Sample } \\
\text { size }\end{array}$ \\
\hline \multicolumn{8}{|c|}{ National samples } \\
\hline Comoros & $\begin{array}{l}\text { Guthold, } 2008 \\
\text { (2002-2003) }\end{array}$ & $\begin{array}{l}\text { World Health } \\
\text { Survey }\end{array}$ & $<600$ MET-minutes/week & IPAQ & 2.7 & $18-69$ & 1492 \\
\hline Jordan & $\begin{array}{l}\text { Zindah, } 2008 \\
(2004)\end{array}$ & $\begin{array}{l}\text { Behavioral Risk } \\
\text { Factor Surveillance } \\
\text { System }\end{array}$ & $\begin{array}{l}\text { Not engaging in moderate } \\
\text { activity (resulting in light } \\
\text { sweating, small increases } \\
\text { in breathing or heart rate. }\end{array}$ & NA & 51.8 & $18+$ & 710 \\
\hline \multirow[t]{3}{*}{ Kuwait } & $\begin{array}{l}\text { Ahmed, } 2013 \\
\text { (2002-2009) }\end{array}$ & $\begin{array}{l}\text { National Nutrition } \\
\text { Surveillance Data }\end{array}$ & $\begin{array}{l}\text { No deliberate non-work related } \\
\text { exercise outside the home such } \\
\text { as walking, running or cycling }\end{array}$ & NA & 68.4 & $20+$ & 32811 \\
\hline & $\begin{array}{l}\text { Al-Zenki, } 2012 \\
(2008-2009)\end{array}$ & NA & $\begin{array}{l}\text { Neither moderately nor very } \\
\text { active }^{a}\end{array}$ & NA & 77.1 & $20+$ & 765 \\
\hline & Alarouj, 2013 (NA) & NA & $\begin{array}{l}\text { Neither moderate nor vigorous } \\
\text { physical activity }^{\mathrm{a}}\end{array}$ & NA & 63.0 & $20-65$ & 1970 \\
\hline \multirow[t]{3}{*}{ KSA } & $\begin{array}{l}\text { Al-Baghli, } 2008 \\
(2004-2005)\end{array}$ & NA & $\begin{array}{l}\text { No physical activity or mild } \\
\text { physical activity (ordinary } \\
\text { housework, walking) }\end{array}$ & NA & 79.2 & $30+$ & 197681 \\
\hline & $\begin{array}{l}\text { Al-Nozha, } 2007 \\
(1995-2000)\end{array}$ & $\begin{array}{l}\text { Coronary Artery } \\
\text { Disease in Saudis } \\
\text { Study (CADISS) }\end{array}$ & $<600$ MET-minutes/week & NA & 96.1 & $30-70$ & 17395 \\
\hline & $\begin{array}{l}\text { Memish, } 2014 \\
\text { (2013) }\end{array}$ & $\begin{array}{l}\text { Saudi Health } \\
\text { Information Survey }\end{array}$ & $\begin{array}{l}\text { Neither moderate nor vigorous } \\
\text { physical activity }\end{array}$ & IPAQ & 69.1 & $15+$ & 10735 \\
\hline \multirow[t]{2}{*}{ Lebanon } & $\begin{array}{l}\text { Farah, } 2015 \\
(2013-2014)\end{array}$ & NA & $\begin{array}{l}\text { Neither moderate-intensity } \\
\text { physical activity for at least } \\
150 \text { min per week or vigorous } \\
\text { intensity physical activity for } \\
75 \text { min at least per week }\end{array}$ & NA & 76.0 & $40+$ & 1515 \\
\hline & $\begin{array}{l}\text { Tohme, 2005 } \\
\text { (2003-2004) }\end{array}$ & NA & $\begin{array}{l}\text { Less than } 30 \text { min of physical } \\
\text { exercise }\end{array}$ & NA & 40.3 & $30+$ & 954 \\
\hline Mauritania & $\begin{array}{l}\text { Guthold, } 2008 \\
\text { (2002-2003) }\end{array}$ & $\begin{array}{l}\text { World Health } \\
\text { Survey }\end{array}$ & $<600$ MET-minutes/week & IPAQ & 61.9 & $18-49$ & 1492 \\
\hline \multirow[t]{2}{*}{ Morocco } & $\begin{array}{l}\text { El Rhazi, } 2011 \\
\text { (2008) }\end{array}$ & NA & Less than 30 min per day & & 38.7 & $18+$ & 2620 \\
\hline & $\begin{array}{l}\text { Najdi, } 2011 \\
\text { (2008) }\end{array}$ & NA & $<3$ METs & IPAQ & 16.5 & $18-99$ & 2613 \\
\hline Palestine & $\begin{array}{l}\text { Baron-Epel, } 2005 \\
\text { (2002-2003) }\end{array}$ & $\begin{array}{l}\text { KAP and } \\
\text { EUROCHIS }\end{array}$ & $\begin{array}{l}\text { Exercising less than once } \\
\text { per week for at least } 20 \\
\text { consecutive minutes }^{\mathrm{b}}\end{array}$ & NA & 62.8 & $21+$ & $1826^{c}$ \\
\hline Tunisia & $\begin{array}{l}\text { Guthold, } 2008 \\
\text { (2002-2003) }\end{array}$ & $\begin{array}{l}\text { World Health } \\
\text { Survey }\end{array}$ & $<600$ MET-minutes/week & IPAQ & 14.6 & $18-69$ & 4332 \\
\hline UAE & $\begin{array}{l}\text { Guthold, } 2008 \\
\text { (2002-2003) }\end{array}$ & $\begin{array}{l}\text { World Health } \\
\text { Survey }\end{array}$ & $<600$ MET-minutes/week & IPAQ & 43.2 & $18-69$ & 1104 \\
\hline \multicolumn{8}{|c|}{ Subnational samples ${ }^{d}$} \\
\hline \multirow[t]{2}{*}{ Bahrain } & $\begin{array}{l}\text { Al-Mahroos, } \\
2001 \text { (NA) }\end{array}$ & NA & $<1 \mathrm{~km}$ walking & $\begin{array}{l}\text { WHO Heart } \\
\text { and Health } \\
\text { Questionnaire }\end{array}$ & 77.5 & $40-69$ & 2013 \\
\hline & $\begin{array}{l}\text { Hamadeh, } \\
2000(N A)\end{array}$ & NA & No exercise & NA & 89.1 & $30-79$ & 516 \\
\hline \multirow[t]{3}{*}{ Egypt } & $\begin{array}{l}\text { Abolfotouh, } 2007 \\
(2002-2003)\end{array}$ & NA & $\begin{array}{l}\text { No non-vigorous physical } \\
\text { activity for at least } 20 \text { minutes } \\
\text { or } 3 \text { times per week }\end{array}$ & NA & 33.8 & $17-25$ & 600 \\
\hline & $\begin{array}{l}\text { Kamel, } 2013 \\
(2010-2011)\end{array}$ & NA & NA & NA & 63.8 & $60+$ & 340 \\
\hline & $\begin{array}{l}\text { Mahfouz, } 2014 \\
(2011)\end{array}$ & NA & No exercise & NA & 78.3 & NA & 300 \\
\hline
\end{tabular}


Table 3 Prevalence of physical inactivity among adults based on findings from published literature (Continued)

\begin{tabular}{|c|c|c|c|c|c|c|c|}
\hline Country & $\begin{array}{l}\text { First author, year } \\
\text { (year of study) }\end{array}$ & Source & Definition & Instrument & Prevalence (\%) & Age range & $\begin{array}{l}\text { Sample } \\
\text { size }\end{array}$ \\
\hline \multirow[t]{4}{*}{ Jordan } & $\begin{array}{l}\text { Centers for Disease, } \\
\text { Control, Prevention, } \\
2003 \text { (2002) }\end{array}$ & $\begin{array}{l}\text { Jordan Behavioral } \\
\text { Risk Factor Survey }\end{array}$ & $\begin{array}{l}\text { Less than having moderate: } \\
\text { activity that caused light sweating } \\
\text { and small increases in heart rate } \\
\text { or breathing for } 30 \text { minutes }\end{array}$ & NA & 47.4 & $18+$ & 8791 \\
\hline & $\begin{array}{l}\text { Mohannad, } \\
2008 \text { (2002) }\end{array}$ & NA & $\begin{array}{l}\text { No activity that caused light } \\
\text { sweating and small increases in } \\
\text { heart rate or breathing }\end{array}$ & NA & 58.7 & $40+$ & 3083 \\
\hline & Kulwicki, 2001 (NA) & NA & No exercise & NA & 22.5 & $17-93$ & 209 \\
\hline & $\begin{array}{l}\text { Madanat, } 2006 \\
(2003)\end{array}$ & NA & $\begin{array}{l}<30 \text { mins of physical activity/ } \\
\text { week }\end{array}$ & NA & 81.5 & Mean: 21.1 & 431 \\
\hline \multirow[t]{7}{*}{ KSA } & $\begin{array}{l}\text { Almurshed, } 2009 \\
\text { (2003-2004) }\end{array}$ & NA & No exercise & NA & 52.0 & $30+$ & 50 \\
\hline & $\begin{array}{l}\text { Al-Quaiz, } 2009 \\
\text { (2007) }\end{array}$ & NA & $\begin{array}{l}\text { Not practicing in any regular } \\
\text { sport and leisure time physical } \\
\text { activity }\end{array}$ & $\begin{array}{l}\text { CDC web site } \\
\text { questionnaire }\end{array}$ & 82.4 & $15-80$ & 450 \\
\hline & $\begin{array}{l}\text { Al-Senany, } \\
2015 \text { (NA) }\end{array}$ & NA & $\begin{array}{l}\text { Less than one hour weekly } \\
\text { activity }\end{array}$ & NA & 69.0 & $60-90$ & 55 \\
\hline & Amin, 2011 (NA) & NA & <600 MET-minutes/week & GPAQ & 48.0 & $18-64$ & 2176 \\
\hline & Amin, 2014 (NA) & NA & $<30$ minutes $/ \geq 5$ days/week & $\mathrm{GPAQ}^{\mathrm{e}}$ & 80.0 & $18-78$ & 2127 \\
\hline & $\begin{array}{l}\text { Awadalla, } 2004 \\
(2012-2013)\end{array}$ & NA & $\begin{array}{l}\text { Neither vigorous: }>6 \text { METs nor } \\
\text { moderate: 3-6 METs }\end{array}$ & $\begin{array}{l}\text { IPAQ } \\
\text { (short form) }\end{array}$ & 58.0 & $17-25$ & 1257 \\
\hline & $\begin{array}{l}\text { Garawi, 2015 } \\
(2004-2005)\end{array}$ & NA & <600 MET-minutes/week & GPAQ & 67.0 & $15-64$ & 4758 \\
\hline Kuwait & $\begin{array}{l}\text { Naser Al-Isa, } \\
2011(\text { NA) }\end{array}$ & NA & $\begin{array}{l}\text { Not engaging in regular } \\
\text { physical activity }\end{array}$ & NA & 45.0 & NA & 787 \\
\hline \multirow[t]{3}{*}{ Lebanon } & $\begin{array}{l}\text { Al-Tannir, } \\
2008 \text { (2007) }\end{array}$ & NA & Less than 3 days/week & NA & 44.5 & $18+$ & 346 \\
\hline & $\begin{array}{l}\text { Musharrafieh, } \\
2008 \text { (2001) }\end{array}$ & NA & Physical exercise for $<0.5 \mathrm{~h} /$ week & NA & 73.6 & Mean: 21.0 & 2013 \\
\hline & $\begin{array}{l}\text { Tamim, 2003 } \\
\text { (2000-2001) }\end{array}$ & NA & $<3$ hours/week & NA & 64.3 & Mean: 21.0 & 1964 \\
\hline Mauritania & $\begin{array}{l}\text { Guthold, } 2008 \\
\text { (2002-2003) }\end{array}$ & $\begin{array}{l}\text { World Health } \\
\text { Survey }\end{array}$ & $<600$ MET-minutes/week & IPAQ & 61.9 & $18-49$ & 2726 \\
\hline \multirow[t]{2}{*}{ Palestine } & $\begin{array}{l}\text { Abdul-Rahim, } \\
2003 \text { (NA) }\end{array}$ & NA & $\begin{array}{l}\text { Occupation-related sedentary- } \\
\text { light PA for men AND no } \\
\text { exercise for women }\end{array}$ & NA & 56.2 & $30-65$ & 936 \\
\hline & $\begin{array}{l}\text { Abu-Mourad, } \\
2008 \text { (2005) }\end{array}$ & NA & No home exercise or sports & NA & 78.0 & $18+$ & 956 \\
\hline \multirow[t]{2}{*}{ Qatar } & $\begin{array}{l}\text { Al-Nakeeb, } \\
2015 \text { (NA) }\end{array}$ & NA & $<840$ MET-min/week & NA & $50.8^{9}$ & Mean $=21.2$ & 732 \\
\hline & Bener, 2004 (2003) & NA & $\begin{array}{l}\text { Not walking, cycling at least } \\
30 \text { minutes/day }\end{array}$ & NA & 55.3 & $25-65$ & 1208 \\
\hline Somalia & Ali, 2015 (2013) & NA & $<2$ hours/week & NA & 33.5 & $18-29$ & 173 \\
\hline Syria & Al Ali, 2011 (2006) & $\begin{array}{l}\text { 2nd Aleppo } \\
\text { Household Survey }\end{array}$ & $\begin{array}{l}\text { Less than } 15 \text { mins/ week of } \\
\text { sport or brisk walking }\end{array}$ & NA & 82.3 & $25+$ & 1168 \\
\hline Tunisia & $\begin{array}{l}\text { Maatoug, } \\
2009 \text { (2009) }\end{array}$ & NA & $\begin{array}{l}<150 \text { mins/week of moderate } \\
\text { level of physical activity }\end{array}$ & $\begin{array}{l}\text { Oxford } \\
\text { Health Alliance } \\
\text { Community } \\
\text { Intervention for } \\
\text { Health Project }\end{array}$ & 44.4 & Mean: 37.9 & 1880 \\
\hline
\end{tabular}


Table 3 Prevalence of physical inactivity among adults based on findings from published literature (Continued)

\begin{tabular}{|c|c|c|c|c|c|c|c|}
\hline Country & $\begin{array}{l}\text { First author, year } \\
\text { (year of study) }\end{array}$ & Source & Definition & Instrument & Prevalence (\%) & Age range & $\begin{array}{l}\text { Sample } \\
\text { size }\end{array}$ \\
\hline \multirow[t]{3}{*}{ UAE } & $\begin{array}{l}\text { Abdulle, } 2006 \\
(2001-2005)\end{array}$ & NA & $\begin{array}{l}\text { Less than one hour, }<3 \text { times } \\
\text { per week }\end{array}$ & NA & 39.4 & $20-75$ & $424^{h}$ \\
\hline & $\begin{array}{l}\text { Mcllvenny, } \\
2000 \text { (NA) }\end{array}$ & NA & No regular exercise & NA & 54.0 & $18-94$ & 254 \\
\hline & $\begin{array}{l}\text { Sabri, } 2004 \\
(2001-2002)\end{array}$ & NA & $<1$ hour/week) of sport & NA & 47.5 & $20-65$ & 436 \\
\hline
\end{tabular}

${ }^{\mathrm{a}}$ Definition of physical activity not specified

${ }^{b}$ It includes: walking, running, swimming playing ball games or any other sports activities (combined every day and nearly every day with once or twice a week)

'Prevalence rate for Arabs only

${ }^{\mathrm{d}}$ One study conducted in Libya by Salam (2012) was excluded from the prevalence table; it includes adolescents and youth (17-24 years) and the prevalence was $65.0 \%$

${ }^{\mathrm{e} C}$ Combined Global Physical Activity Questionnaire (GPAQ) version 2.0 with a modified show card based on World Health Organization STEPs survey

fKuwaiti college students

${ }^{g}$ Only Qatari students

hOnly normotensives

other sociodemographic determinants, reported associations were inconsistent.

Several studies found associations between physical inactivity and lifestyle factors. Predictably, screen time was positively associated with physical inactivity in all eight studies that examined this factor [21-28]. Smoking and alcohol were positively associated with physical inactivity [29-32], while consuming fruits and vegetables was negatively correlated [33]. Four studies found a positive association between physical inactivity and chronic medical conditions [29, 34-36].

The studies we reviewed did not report consistent associations between obesity and physical inactivity: $8 / 13$ found a positive association [22, 24, 29, 33, 35, 37-39], four reported the reverse [30, 40-42] and one showed no effect [43].

Table 4 Prevalence of physical inactivity among children/adolescents using data from Global School-based Student Health Surveys (GSHS) ${ }^{a}$

\begin{tabular}{|c|c|c|c|c|}
\hline Country & Year of study & Age range & Sample size & $\begin{array}{l}\text { Total prevalence of } \\
\text { physical inactivity }\end{array}$ \\
\hline \multicolumn{5}{|c|}{ Definition: $<60$ mins per day on five or more days during the past seven days } \\
\hline Iraq & 2012 & $13-15$ & 2038 & 80.0 \\
\hline Lebanon & 2011 & $13-15$ & 2286 & 65.4 \\
\hline Mauritania & 2010 & $13-15$ & 2063 & 83.7 \\
\hline Morocco & 2010 & $13-15$ & 2924 & 82.6 \\
\hline Palestine (Gaza Strip) & 2010 & $13-15$ & 2677 & 75.8 \\
\hline Palestine (West Bank) & 2010 & $13-15$ & 1908 & 81.7 \\
\hline Qatar & 2011 & $13-15$ & 2021 & 85.0 \\
\hline Sudan & 2012 & $13-15$ & 2211 & 89.0 \\
\hline Syria & 2010 & $13-15$ & 3102 & 84.9 \\
\hline UAE & 2010 & $13-15$ & 2581 & 72.5 \\
\hline \multicolumn{5}{|c|}{ Definition: $<60$ mins per day on all 7 days during the past 7 days } \\
\hline Djibouti & 2007 & $13-15$ & 1777 & 85.1 \\
\hline Egypt & 2006 & $13-15$ & 5249 & 90.6 \\
\hline Jordan & 2007 & $13-15$ & 2197 & 85.6 \\
\hline Kuwait & 2015 & $13-17$ & 3637 & 84.4 \\
\hline Libya & 2007 & $13-15$ & 2242 & 83.9 \\
\hline Oman & 2015 & $13-17$ & 3468 & 88.3 \\
\hline Tunisia & 2008 & $13-15$ & 2870 & 81.5 \\
\hline Yemen & 2008 & $13-15$ & 1175 & 84.8 \\
\hline
\end{tabular}

${ }^{\mathrm{a}}$ All based on nationally representative samples 


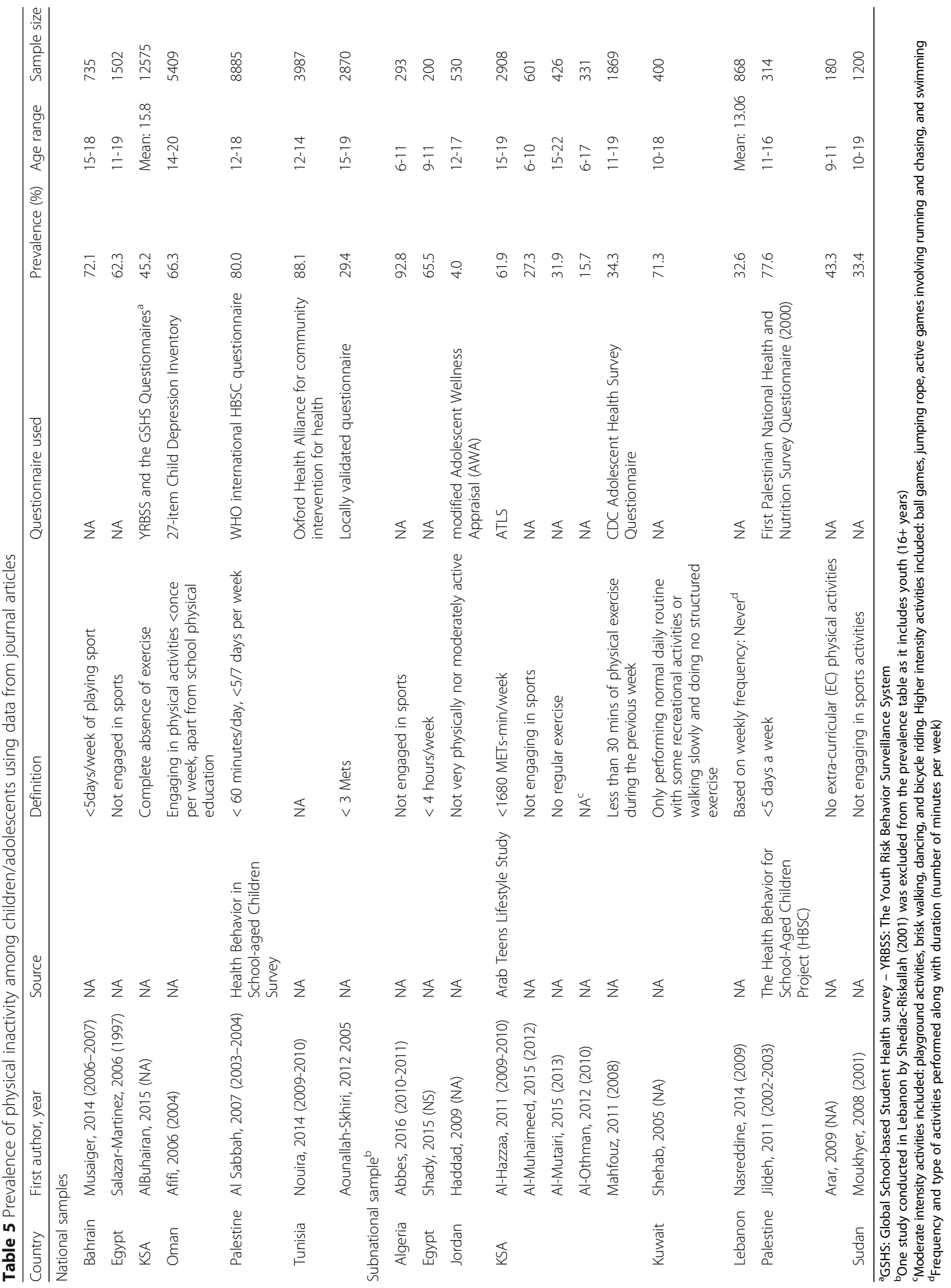




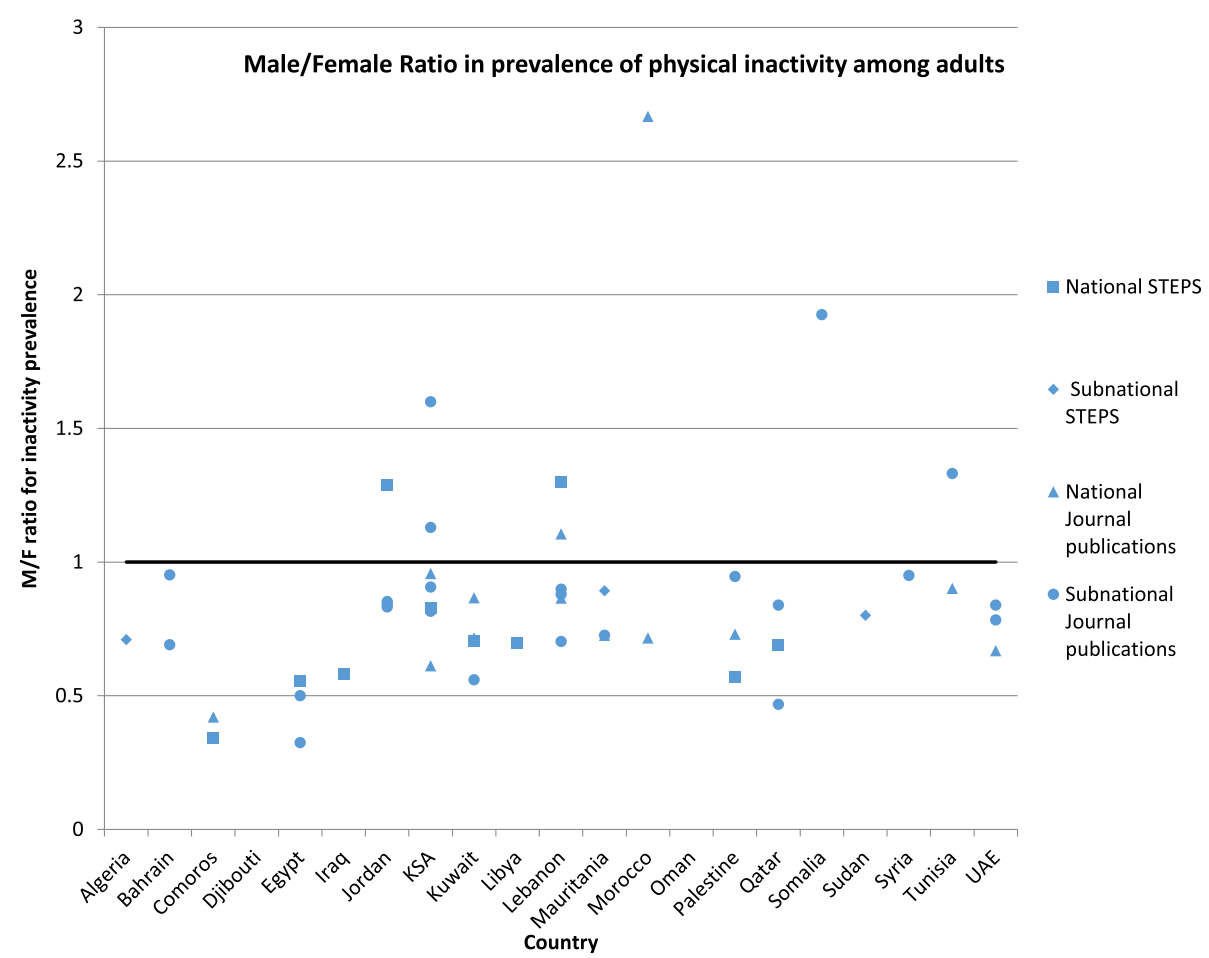

Fig. 2 Gender differences in prevalence of physical inactivity among adults

\section{Barriers to Physical activity}

We examined the subset of studies that investigated barriers to exercise. Some reported reasons were shared with other parts of the world, while others were specific to the Arab region. It is clear that the hot climate of the Arabian Peninsula and Gulf countries limits outdoor physical activity to relatively short seasons and requires special indoor facilities [13, 38, 44-52]. In addition in most countries, the built environment, inadequate public transportation systems, and lack of spaces for walkers or joggers discourage exercise $[15,20,26,31,38,42,46,47$, 53-68]. As in other studies, time constraints were

Male/Female Ratio in prevalence of physical inactivity among children/adolescents

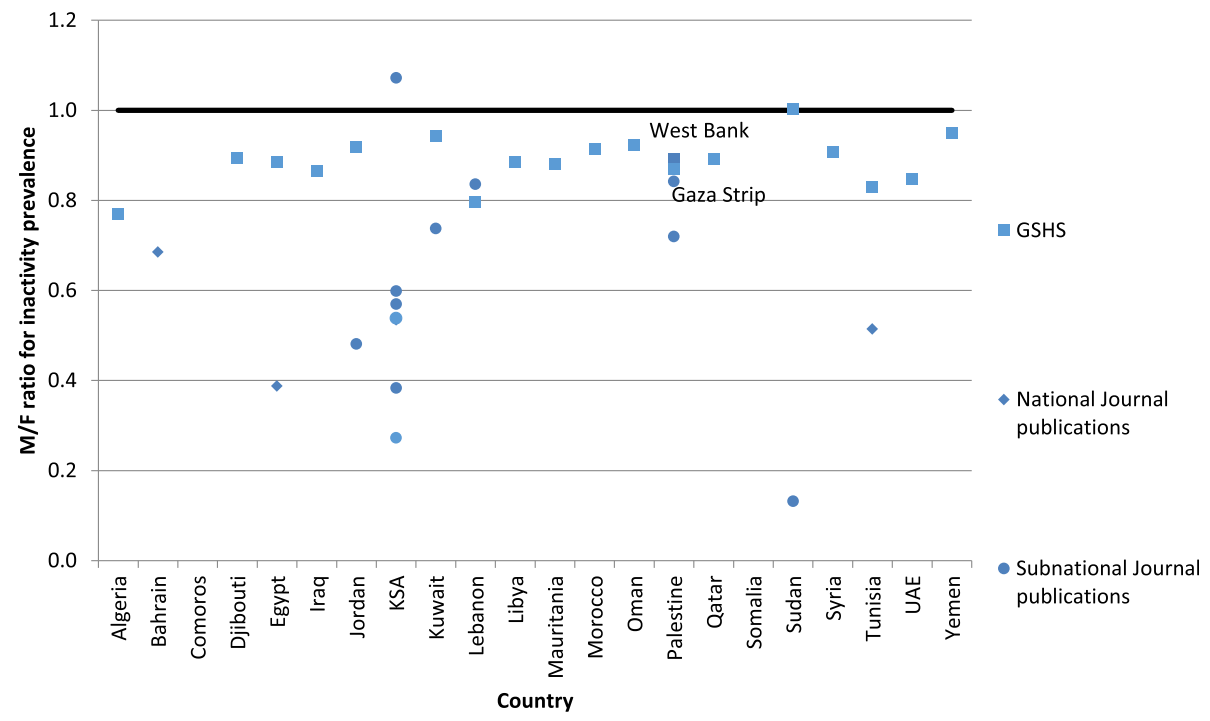

Fig. 3 Gender differences in prevalence of physical inactivity among children/adolescents 
Table 6 Factors associated with physical inactivity in Arab countries

\begin{tabular}{|c|c|c|c|}
\hline & \multicolumn{3}{|l|}{ Statistical association with physical inactivity } \\
\hline & Positive & Negative & $\begin{array}{l}\text { Other } \\
\text { associations }\end{array}$ \\
\hline$\overline{\text { Age }^{a}}$ & $\begin{array}{l}{[13,29,35,36,38,39,69,73,83,92,100,135,143,153,} \\
176,218,221,231]\end{array}$ & {$[44,71,142]$} & $\begin{array}{l}\text { U shape [63, } \\
\text { 202] } \\
\text { Curvilinear [41] }\end{array}$ \\
\hline Marital status & {$[29,37,38,41,105,181,232]$} & {$[42,79,221]$} & \\
\hline Educational level ${ }^{a, b}$ & {$[35,54]$} & $\begin{array}{l}{[30,33,38,41,42,46,92,100,148,150,171} \\
218,231,232]\end{array}$ & $\begin{array}{l}\text { No effect [34, } \\
69,93]\end{array}$ \\
\hline Employment $^{\mathrm{a}}$ & {$[54,150]$} & {$[30,33,36,92,183,232]$} & \\
\hline$S E S^{a, c}$ & {$[12,35,46,75,105,232]$} & {$[42,44,54,92,181]$} & U shape [83] \\
\hline Urban residence & {$[35,36,43,77,150]$} & & \\
\hline $\begin{array}{l}\text { Consuming fruits/ } \\
\text { vegetables }\end{array}$ & & [33] & \\
\hline Smoking ${ }^{a}$ & [29-32] & [225] & \\
\hline Alcohol & {$[30]$} & & \\
\hline Screen time ${ }^{d}$ & [21-28] & & \\
\hline Overweight/ Obesity & {$[22,24,29,33,35,37-39]$} & {$[30,40-42]$} & No effect [43] \\
\hline $\begin{array}{l}\text { Chronic medical } \\
\text { conditions }^{a}\end{array}$ & {$[29,34-36]$} & & \\
\hline Parity & [107] & & \\
\hline
\end{tabular}

mentioned as barriers $[15,26,28,30,31,40-42,46$, $52,54,67,69-73]$, in addition to insufficient motivation or interest $[25,26,34,44,46,54,71,73]$, other priorities [26], and lack of skills [26, 44].

A particularity of the region is the lack of encouragement for physical activity by many parents, who appear to favor educational and spiritual activities over physical activities for their children. Lack of support for physical activity is also noted among friends, peers, and even teachers, in studies conducted in Saudi Arabia, Egypt, and Jordan [15, 20, 24-26, 30, 42, 46, 53-55, 64, 66, 68, 71, 74]. Another regionally specific factor relates to gender constraints: even where fitness facilities are available, as is the case in the more affluent countries of the region, accessibility is a problem, particularly for women.

Lower physical activity among women has been attributed to gender norms, including conservative dress that is not suitable for physical activity, the need for women to be chaperoned in public spaces, and the paucity of gendersegregated fitness facilities [15, 28, 62, 64, 67, 71, 75, 76]. In addition, cultural values put a premium on comfort for both genders, physical exertion is avoided, and public spaces such as streets are not considered appropriate for physical activity. Thus, both general norms and gender norms converge to discourage physical activity $[15,27,31,41,45-47,54,60,62-64,67,74,75,77-86]$.

\section{Discussion}

The diversity of definitions and methods among studies published in journals and the fact that only 43/157 studies used validated instruments hampers comparisons of the prevalence and correlates of physical activity, and it is possible that some of the differences we found are artifactual. Using inactivity instead of activity improves the comparability, but it is clear that harmonizing definitions and measurements and considering the multidimensional aspects of physical activity would improve the evidence for the region.

Despite these limitations, it is possible to discern some patterns. The results of this review indicate that throughout the region, levels of physical inactivity are very high. Inactivity among adults is $40 \%$ or higher in all but five of the fifteen countries with nationally representative surveys; studies with smaller samples suggest even higher levels of inactivity (>60\%). Among children and adolescents, inactivity is alarmingly high, around $80 \%$ in all national surveys except Tunisia.

High inactivity among children and adolescents is documented in other regions $[87,88]$ and is a worldwide problem, but the levels of adult inactivity we found in this review compare very unfavorably with those of other regions. Inactivity levels in Europe, the western Pacific, Africa, and southeast Asia are considerably lower (25\%, 
$34 \%, 28 \%$ and $17 \%$ respectively [88-90]); they are even lower in South-East Asia and Africa (15\% and 21\% respectively); the Americas have lower or similar inactivity levels [88-90]. These high levels of inactivity indicate that social circumstances in many countries of the region do not seem to encourage physical activity. Some comparative analyses across countries in the Arab region and outside it have reported that Muslim countries were more likely to be physically inactive, and seemed to suggest that religion constitutes an obstacle to physical activity [91]. This however is not consistent with the diverse interpretations of religious doctrine in the region, and the fact that there are no grounds for arguing that Islamic doctrine is antithetical to exercise. In addition, there is no evidence linking religious observance to lower activity. The one study that compared Muslims and non-Muslims, conducted in Syria, found no significant differences in physical activity between Muslim Syrians and Syrians belonging to other religious groups [92]. Such research highlights the complex interplay among the multiple factors that hinder physical activity.

Physical and social barriers to exercise have been amply documented in multiple Arab countries: the hot weather discourages walking and exertion outdoors; an unfriendly built environment hinders exercise and promotes a car culture; physical exertion is associated with lower status occupations; a premium is placed on comfort; all these contribute to devaluing and discouraging exercise. That parental preferences favor spiritual and educational, over physical activities, and social gatherings are the main leisure activity further contributes to reducing physical activity and encouraging sedentarity $[93,94]$.

The combination of physical obstacles and low valuations translates into insufficient interest and motivation to exercise, which are documented in multiple countries $[20,46,52,68,90]$. A number of studies $[24,40,71,74$, 95-101] bring out the clustering of health risks within the studied populations, whereby physical activity is one among a set of lifestyle factors that may include energy dense foods, sweet drinks, sedentariness, and unsafe driving. This suggests that lack of knowledge about healthy behaviors in general contributes to inactivity, and emphasizes the role of social activities that are focused on sedentarity and unhealthy snacking. Interestingly, studies [72] that have probed into perceptions of health behaviors have found these to be limited to hygiene, rest and diet, but not physical activity. Thus a combination of material and cultural factors translates into barriers to physical activity at multiple levels and to a lack of awareness and motivation among the population.

A striking result of this analysis is the consistency of gender differences in physical inactivity: in nearly all $(45 / 53)$ studies conducted among adults and (31/32) among children/adolescents, prevalence of inactivity was higher among women/girls. While traditional religious norms have been reported to potentially define acceptable behaviors for women and preclude exercising, careful qualitative research $[76,102]$ shows that these are not insurmountable obstacles. Studies show that some women athletes negotiate their involvement in sports even as they continue to wear Islamic clothing, and that decisions to exercise are influenced by new ideas about healthy lifestyles disseminated by professionals. In addition, some studies [103] suggest that ideas about physical activity can become more positive, and that cultural barriers can be overcome when adequate facilities are available.

Studies on ideas about the body report preferences for heavier shapes, especially for men [104] and ethnographic research indicates that there is a normalization of weight gain with increasing age and with maternal status among women $[105,106]$. Such notions of the body likely translate into a lack of motivation to exercise and maintain optimal weight across the life cycle for both sexes, and women are vulnerable to weight gain with successive pregnancies. Women's marginalization in segregated societies [107] further pushes them towards a lifestyle centered on hospitality, excessive food consumption and sedentariness. But research also indicates that ideal body shapes can change as a result of exposure to media, as younger women in several countries of the region seem to have adopted thinner body shape preferences [108]. Ideas about exercise can also be transformed by initiatives that provide information about the link between health and exercise, activities that involve women in sports, and efforts to change societal valuations of exertion-and of women [109].

Some initiatives, inspired by those in other regions [110] are underway: policies have been formulated in Oman and Qatar; healthy lifestyles including exercise have been promoted in Morocco, Bahrain and Palestine [111]; some have reported success in improving physical activity in Dubai [89], and Oman [112], while others, such as school-based interventions $[113,114]$ in Lebanon and Tunisia did not report improvements in physical activity or reductions in screen time. A closer examination of these interventions' successes and failures can provide useful lessons for future efforts.

\section{Conclusions}

The high levels of inactivity in the region call for considerable efforts to tackle the material and socio-cultural aspects of the cultural context that discourage physical activity. Multi-sectoral efforts are needed, including collaborations among ministries of health, sports, youth and education, as well as wider collaborations that involve sectors such as transport, environment and urban planning $[16,111,115]$. 


\section{Additional file}

Additional file 1: Medline search strategy. (DOCX $13 \mathrm{~kb}$ )

\begin{abstract}
Abbreviations
ATLS: Arab Teens Lifestyle Study; DALYs: Disability Adjusted Life Years; GPAQ: Global Physical Activity Questionnaire; GSHS: Global School-based Student Health Surveys; IPAQ: International Physical Activity Questionnaire; KPAS: Kaiser Physical Activity Survey; KSA: Kingdom of Saudi Arabia; LASA: Longitudinal Aging Study Amsterdam; MESA: Multi-Ethnic Study of Atherosclerosis questionnaire; ODK: Open Data Kit; PACE+: Patient-Centered Assessment and Counseling for Exercise Plus Nutrition; PRISMA: Preferred Reporting Items for Systematic Reviews and Meta-Analyses; SSCI: Social Sciences Citation Index; UAE: United Arab Emirates; WHO STEPS: World Health Organization STEPwise approach to Surveillance; WHO: World Health Organization; WHS: World Health Surveys; YRBSS: The Youth Risk Behavior Surveillance System
\end{abstract}

\section{Acknowledgements}

This work was funded in part by a grant (106981-001) from the International Development Research Centre (IDRC) in Canada. The funder had no role in the design of the study and collection, analysis, and interpretation of data and in writing the manuscript.

We would like to thank Dr. Regina Guthold of the World Health Organization, for her constructive comments on a previous draft of the manuscript, and Zeina Jamaluddine for assisting with the preparation of the data extraction protocol.

\section{Funding}

This work was funded by a grant (106981-001) from the International Development Research Centre (IDRC) in Canada. The funder had no role in the design of the study and collection, analysis, and interpretation of data and in writing the manuscript.

\section{Availability of data and materials}

Data were extracted from published sources. Data sharing not applicable.

\section{Authors' contributions}

ES drafted the paper and conducted data screening, extraction, analysis and interpretation; CA conducted the search and data screening; CA and HG supervised the work and contributed to data analysis, interpretation and writing. CMO designed the analysis, supervised the work and critically reviewed the paper. All authors read and approved the final manuscript.

\section{Ethics approval and consent to participate}

Not applicable.

\section{Competing interests}

The authors declare that they have no competing interests.

\section{Publisher's Note}

Springer Nature remains neutral with regard to jurisdictional claims in published maps and institutional affiliations.

\section{Author details}

${ }^{1}$ Center for Research on Population and Health, Faculty of Health Sciences, American University of Beirut, P.O. Box 11-0236/EPHD, Riad El Solh, Beirut, Lebanon. ${ }^{2}$ Institute for Advanced Study, Aix-Marseille University, Marseille, France.

Received: 4 October 2017 Accepted: 17 April 2018

Published online: 18 May 2018

\section{References}

1. World Health Organization. Global Strategy on Diet, Physical Activity and Health. n.d. http://www.who.int/dietphysicalactivity/factsheet_inactivity/en/. Accessed 16 Feb 2017.

2. World Health Organization. Physical activity. 2017. http://www.who.int/ topics/physical_activity/en/. Accessed Feb 2017.
3. Taylor RS, Brown A, Ebrahim S, Jolliffe J, Noorani H, Rees K, et al. Exercisebased rehabilitation for patients with coronary heart disease: systematic review and meta-analysis of randomized controlled trials. Am J Med. 2004;116(10):682-92.

4. Blair SN, Cheng Y, Holder JS. Is physical activity or physical fitness more important in defining health benefits? Med Sci Sports Exerc. 2001;33(6; SUPP):S379-S99.

5. Aune D, Sen A, Prasad M, Norat T, Janszky I, Tonstad S, et al. BMI and all cause mortality: systematic review and non-linear dose-response metaanalysis of 230 cohort studies with 3.74 million deaths among 30.3 million participants. BMJ. 2016;353:i2156.

6. Fogelholm M. Physical activity, fitness and fatness: relations to mortality, morbidity and disease risk factors. A systematic review. Obes Rev. 2010;11(3):202-21.

7. Institute for Health Metrics and Evaluation (IHME). GBD Compare. IHME, University of Washington, Seattle, WA. 2015. http://vizhub.healthdata.org/ gbd-compare. Accessed July 2016.

8. Kilpi F, Webber L, Musaigner A, Aitsi-Selmi A, Marsh T, Rtveladze K, et al. Alarming predictions for obesity and non-communicable diseases in the Middle East. Public Health Nutr. 2014;17(05):1078-86.

9. Mokdad AH, Jaber S, Aziz MIA, AlBuhairan F, AlGhaithi A, AlHamad NM, et al. The state of health in the Arab world, 1990-2010: an analysis of the burden of diseases, injuries, and risk factors. The Lancet. 2014;383(9914):309-20.

10. Tailakh A, Evangelista LS, Mentes JC, Pike NA, Phillips LR, Morisky DE. Hypertension prevalence, awareness, and control in Arab countries: a systematic review. Nurs Health Sci. 2014;16(1):126-30.

11. Al Subhi LK, Bose S, Al Ani MF. Prevalence of Physically Active and Sedentary Adolescents in 10 Eastern Mediterranean Countries and its Relation With Age, Sex, and Body Mass Index. J Phys Act Health. 2015;12(2): 257-65. https://doi.org/10.1123/jpah.2013-0134.

12. Dumith SC, Hallal PC, Reis RS, Kohl HW 3rd. Worldwide prevalence of physical inactivity and its association with human development index in 76 countries. Prev Med. 2011;53(1-2):24-8.

13. Guthold R, Ono T, Strong KL, Chatterji S, Morabia A. Worldwide variability in physical inactivity a 51-country survey. Am J Prev Med. 2008;34(6):486-94.

14. Mabry R, Koohsari MJ, Bull F, Owen N. A systematic review of physical activity and sedentary behaviour research in the oil-producing countries of the Arabian Peninsula. BMC Public Health. 2016;16(1):1003.

15. Musaiger AO, Al-Mannai M, Tayyem R, Al-Lalla O, Ali EY, Kalam F, et al. Perceived barriers to healthy eating and physical activity among adolescents in seven Arab countries: a cross-cultural study. ScientificWorldJournal. 2013;2013:232164.

16. Reis RS, Salvo D, Ogilvie D, Lambert EV, Goenka S, Brownson RC et al. Scaling up physical activity interventions worldwide: stepping up to larger and smarter approaches to get people moving. Lancet. 2016;388(10051):1337-48.

17. Shea BJ, Grimshaw JM, Wells GA, Boers M, Andersson N, Hamel C, et al. Development of AMSTAR: a measurement tool to assess the methodological quality of systematic reviews. BMC Med Res Methodol. 2007;7(1):10.

18. Moher D, Liberati A, Tetzlaff J, Altman DG. Preferred reporting items for systematic reviews and meta-analyses: the PRISMA statement. Annals of internal medicine. 2009:151(4):264-9.

19. Al-Hazzaa HM. Pedometer-determined physical activity among obese and non-obese 8- to 12-year-old Saudi schoolboys. J Physiol Anthropol. 2007; 26(4):459-65.

20. Al-Hazzaa HM, Al-Rasheedi AA. Adiposity and physical activity levels among preschool children in Jeddah, Saudi Arabia. Saudi Medical Journal. 2007; 28(5):766-73.

21. Salazar-Martinez E, Allen B, Fernandez-Ortega C, Torres-Mejia G, Galal O, Lazcano-Ponce E. Overweight and obesity status among adolescents from Mexico and Egypt. Arch Med Res. 2006;37(4):535-42.

22. Chacar HR, Salameh P. Public schools adolescents' obesity and growth curves in Lebanon. J Med Liban. 2011;59(2):80-8.

23. Bener A, Al-Mahdi HS, Vachhani PJ, Al-Nufal M, Ali Al. Do excessive internet use, television viewing and poor lifestyle habits affect low vision in school children? J Child Health Care. 2010;14(4):375-85. https://doi.org/10.1177/ 1367493510380081

24. Al-Nakeeb Y, Lyons M, Collins P, Al-Nuaim A, Al-Hazzaa H, Duncan MJ, et al. Obesity, physical activity and sedentary behavior amongst British and Saudi youth: a cross-cultural study. Int J Environ Res Public Health. 2012;9(4):1490-506.

25. Alquaiz AM, Kazi A, Qureshi R, Siddiqui AR, Jamal A, Shaik SA. Correlates of Cardiovascular Disease Risk Scores in Women in Riyadh, Kingdom of Saudi Arabia. Women Health. 2015;55(1):103-17. https://doi.org/10.1080/03630242. 2014.972020. 
26. Awadalla NJ, Aboelyazed AE, Hassanein MA, Khalil SN, Aftab R, Gaballa II, et al. Assessment of physical inactivity and perceived barriers to physical activity among health college students, south-western Saudi Arabia. East Mediterr Health J. 2014;20(10):596-604.

27. Mahfouz AA, Shatoor AS, Khan MY, Daffalla AA, Mostafa OA, Hassanein MA. Nutrition, physical activity, and gender risks for adolescent obesity in Southwestern Saudi Arabia. Saudi J Gastroenterol. 2011;17(5):318-22.

28. Ali HI, Baynouna LM, Bernsen RM. Barriers and facilitators of weight management: perspectives of Arab women at risk for type 2 diabetes. Health Soc Care Community. 2010;18(2):219-28.

29. Al-Tannir M, Kobrosly S, Itani T, El-Rajab M, Tannir S. Prevalence of physical activity among Lebanese adults: a cross-sectional study. J Phys Act Health. 2009;6(3):315-20.

30. Musharrafieh U, Tamim HM, Rahi AC, El-Hajj MA, Al-Sahab B, El-Asmar K, et al. Determinants of university students physical exercise: a study from Lebanon. Int J Public Health. 2008;53(4):208-13.

31. Aounallah-Skhiri $\mathrm{H}$, Ben Romdhane $\mathrm{H}$, Maire B, Elkhdim H, Eymard-Duvernay S, Delpeuch F, et al. Health and behaviours of Tunisian school youth in an era of rapid epidemiological transition. East Mediterr Health J. 2009;15(5):1201-14.

32. Maatoug J, Harrabi I, Hmad S, Belkacem M, Al'absi M, Lando H, et al. Clustering of risk factors with smoking habits among adults, Sousse, Tunisia. Prev Chronic Dis. 2013;10:E211.

33. Mabry R, Winkler E, Reeves M, Eakin E, Owen N. Correlates of Omani adults' physical inactivity and sitting time. Public Health Nutr. 2013;16(1):65.

34. Hallaj FA, El Geneidy MM, Mitwally HH, Ibrahim HS. Activity patterns of residents in homes for the elderly in Alexandria, Egypt. East Mediterr Health J. 2010;16(11):1183-8.

35. Sibai AM, Costanian C, Tohme R, Assaad S, Hwalla N. Physical activity in adults with and without diabetes: from the 'high-risk' approach to the 'population-based' approach of prevention. BMC Public Health. 2013;13:1002.

36. Amin TT, Al Khoudair AS, Al Harbi MA, Al Ali AR. Leisure time physical activity in Saudi Arabia: prevalence, pattern and determining factors. Asian Pac J Cancer Prev. 2012;13(1):351-60.

37. Al-Isa AN, Campbell J, Desapriya E, Social WN. Health Factors Associated with Physical Activity among Kuwaiti College Students. J Obes. 2011;2011: 512363-6. https://doi.org/10.1155/2011/512363.

38. Al-Nozha MM, Al-Hazzaa HM, Arafah MR, Al-Khadra A, Al-Mazrou YY, AlMaatouq MA, et al. Prevalence of physical activity and inactivity among Saudis aged 30-70 years. A population-based cross-sectional study. Saudi Med J. 2007:28(4):559-68.

39. Najdi A, El Achhab Y, Nejjari C, Norat T, Zidouh A, El Rhazi K. Correlates of physical activity in Morocco. Prev Med. 2011;52(5):355-7.

40. Al-Nakeeb Y, Lyons M, Dodd LJ, Al-Nuaim A. An Investigation into the Lifestyle, Health Habits and Risk Factors of Young Adults. Int J Environ Res Public Health. 2015;12(4):4380-94. https://doi.org/10.3390/ijerph120404380.

41. Al-Refaee SA, Al-Hazzaa HM. Physical activity profile of adult males in Riyadh City. Saudi Med J. 2001;22(9):784-9.

42. Khalaf A, Ekblom O, Kowalski J, Berggren V, Westergren A, Al-Hazzaa H. Female university students' physical activity levels and associated factors-a cross-sectional study in southwestern Saudi Arabia. Int J Environ Res Public Health. 2013;10(8):3502-17.

43. Aounallah-Skhiri $H$, Romdhane HB, Traissac P, Eymard-Duvernay S, Delpeuch $F$, Achour N, et al. Nutritional status of Tunisian adolescents: associated gender, environmental and socio-economic factors. Public Health Nutr. 2008;11(12):1306-17.

44. AIQuaiz AM, Tayel SA. Barriers to a healthy lifestyle among patients attending primary care clinics at a university hospital in Riyadh. Ann Saudi Med. 2009. 29(1):30-5.

45. Baglar R. "Oh God, save us from sugar": an ethnographic exploration of diabetes mellitus in the United Arab Emirates. Med Anthropol. 2013;32(2): 109-25.

46. El-Gilany AH, Badawi K, El-Khawaga G, Awadalla N. Physical activity profile of students in Mansoura University, Egypt. East Mediterr Health J. 2011;17(8): 694-702.

47. Kim HJ, Choi-Kwon S, Kim H, Park YH, Koh CK. Health-promoting lifestyle behaviors and psychological status among Arabs and Koreans in the United Arab Emirates. Res Nurs Health. 2015;38(2):133-41.

48. Memish ZA, Jaber S, Mokdad AH, AlMazroa MA, Murray CJL, Al Rabeeah AA et al. Burden of Disease, Injuries, and Risk Factors in the Kingdom of Saudi Arabia, 1990-2010. Prev. Chronic Dis. 2014;11 https://doi.org/10.5888/pcd11. 140176.
49. Musaiger AO, Al-Kandari Fl, Al-Mannai M, Al-Faraj AM, Bouriki FA, Shehab FS, et al. Perceived barriers to weight maintenance among university students in Kuwait: the role of gender and obesity. Environ Health Prev Med. 2014; 19(3):207-14.

50. Rahim HFA, Sibai A, Khader Y, Hwalla N, Fadhil I, Alsiyabi H, et al. Noncommunicable diseases in the Arab world. Lancet. 2014;383(9914):356-67. https://doi.org/10.1016/s0140-6736(13)62383-1.

51. Al-Baghli NA, Al-Ghamdi AJ, Al-Turki KA, El-Zubaier AG, Al-Ameer MM, Overweight A-BFA. obesity in the eastern province of Saudi Arabia. Saudi Med J. 2008;29(9):1319-25.

52. Al-Mutairi RL, Bawazir AA, Ahmed AE, Jradi H. Health Beliefs Related to Diabetes Mellitus Prevention among Adolescents in Saudi Arabia. Sultan Qaboos Univ Med J. 2015;15(3):e398-404.

53. Al-Hazzaa HM, Al-Nakeeb Y, Duncan MJ, Al-Sobayel HI, Abahussain NA, Musaiger AO, et al. A cross-cultural comparison of health behaviors between Saudi and British adolescents living in urban areas: gender by country analyses. Int J Environ Res Public Health. 2013;10(12):6701-20.

54. Amin TT, Suleman W, Ali A, Gamal A, Al Wehedy A. Pattern, prevalence, and perceived personal barriers toward physical activity among adult Saudis in Al-Hassa, KSA. J Phys Act Health. 2011;8(6):775-84.

55. Arar KH, Rigbi A. 'To participate or not to participate?'status and perception of physical education among Muslim Arab-Israeli secondary school pupils. Sport Educ Soc. 2009;14(2):183-202. https://doi.org/10.1080/13573320902809088.

56. El Ansari W, Khalil K, Crone D, Stock C. Physical activity and gender differences: correlates of compliance with recommended levels of five forms of physical activity among students at nine universities in Libya. Cent Eur J Public Health. 2014;22(2):98-105.

57. Fazah A, Jacob C, Moussa E, El-Hage R, Youssef H, Delamarche P. Activity, inactivity and quality of life among Lebanese adolescents. Pediatr Int. 2010; 52(4):573-8.

58. Guthold R. Physical Activity and Sedentary Behavior Among Schoolchildren: A 34-Country Comparison. J Pediatr. 2010;157(1):43-9.e1. https://doi.org/10. 1016/j.jpeds.2010.01.019.

59. Jabre $P$, Sikias $P$, Khater-Menassa B, Baddoura R, Awada H. Overweight children in Beirut: prevalence estimates and characteristics. Child: Care, Health \& Development. 2005:31(2):159-65.

60. Nsour M, Mahfoud Z, Kanaan MN, Prevalence BA. predictors of nonfatal myocardial infarction in Jordan. East Mediterr Health J. 2008;14(4):818-30.

61. Rguibi M, Belahsen R. Overweight and obesity among urban Sahraoui women of South Morocco. Ethn. Dis. 2004;14(4):542-547.

62. Rguibi M, Belahsen R. High blood pressure in urban Moroccan Sahraoui women. J Hypertens. 2007;25(7):1363-8.

63. Shediac-Rizkallah MC, Soweid RA, Farhat TM, Yeretzian J. Adolescent healthrelated behaviors in postwar Lebanon: findings among students at the American University of Beirut. Int Q Community Health Educ. 2001;20(2):115-31.

64. Madanat $H$, Merrill RM. Motivational factors and stages of change for physical activity among college students in Amman, Jordan. Promot Educ. 2006;13(3):185-90

65. Alam AA. Obesity among female school children in North West Riyadh in relation to affluent lifestyle. Saudi Med J. 2008;29(8):1139-44.

66. Al-Hazzaa HM, Abahussain NA, Al-Sobayel HI, Qahwaji DM, Musaiger AO. Physical activity, sedentary behaviors and dietary habits among Saudi adolescents relative to age, gender and region. Int J Behav Nutr Phys Act. 2011:8:140.

67. Berger G, Peerson A. Giving young Emirati women a voice: participatory action research on physical activity. Health Place. 2009:15(1):117-24.

68. Alsubaie AS, Omer EO. Physical Activity Behavior Predictors, Reasons and Barriers among Male Adolescents in Riyadh, Saudi Arabia: Evidence for Obesogenic Environment. Int J Health Sci (Qassim). 2015;9(4):400-8.

69. Al-Hazzaa HM. Health-enhancing physical activity among Saudi adults using the International Physical Activity Questionnaire (IPAQ). Public Health Nutr. 2007;10(1):59-64.

70. Ammouri AA, Neuberger G, Nashwan AJ, Al-Haj AM. Determinants of selfreported physical activity among Jordanian adults. J Nurs Scholarsh. 2007; 39(4):342-8

71. Mabry RM, Al-Busaidi ZQ, Reeves MM, Owen N, Eakin EG. Addressing physical inactivity in Omani adults: perceptions of public health managers. Public Health Nutr. 2014;17(3):674-81.

72. Mahasneh SM. Health perceptions and health behaviours of poor urban Jordanian women. J Adv Nurs. 2001;36(1):58-68.

73. Al-Gelban KS. Dietary habits and exercise practices among the students of a Saudi Teachers' Training College. Saudi Med J. 2008;29(5):754-9. 
74. Abolfotouh MA, Bassiouni FA, Mounir GM, Fayyad R. Health-related lifestyles and risk behaviours among students living in Alexandria University Hostels. East Mediterr Health J. 2007;13(2):376-91.

75. El Rhazi K, Nejjari C, Zidouh A, Bakkali R, Berraho M, Barberger Gateau P. Prevalence of obesity and associated sociodemographic and lifestyle factors in Morocco. Public Health Nutr. 2011;14(1):160-7.

76. Lachheb M. Religion in practice. The veil in the sporting space in Tunisia. Social Compass. 2012;59(1):120-35.

77. Abdul-Rahim HF, Holmboe-Ottesen G, Stene LC, Husseini A, Giacaman R, Jervell J, et al. Obesity in a rural and an urban Palestinian West Bank population. Int J Obes Relat Metab Disord. 2003;27(1):140-6.

78. Al Junaibi A, Abdulle A, Sabri S, Hag-Ali M, Nagelkerke N. The prevalence and potential determinants of obesity among school children and adolescents in Abu Dhabi, United Arab Emirates. Int J Obes (Lond). 2013;37(1):68-74.

79. Al-Kandari F, Vidal VL. Correlation of the health-promoting lifestyle, enrollment level, and academic performance of College of Nursing students in Kuwait. Nurs Health Sci. 2007;9(2):112-9.

80. Gharaibeh M, Al-Ma'aitah R, Al Jada N. Lifestyle practices of Jordanian pregnant women. Int Nurs Rev. 2005;52(2):92-100.

81. Haddad LG, Owies A, Mansour A. Wellness appraisal among adolescents in Jordan: a model from a developing country: a cross-sectional questionnaire survey. Health Promot Int. 2009;24(2):130-9.

82. Musaiger AO, Al-Roomi K, Bader Z. Social, dietary and lifestyle factors associated with obesity among Bahraini adolescents. Appetite. 2014;73:197-204. https://doi.org/10.1016/j.appet.2013.11.002.

83. Ng SW, Zaghloul S, Ali H, Harrison G, Yeatts K, El Sadig M, et al. Nutrition transition in the United Arab Emirates. Eur J Clin Nutr. 2011;65(12):1328-37.

84. Rguibi M, Belahsen R. Fattening practices among Moroccan Saharawi women. East Mediterr Health J. 2006:12(5):619-24.

85. Rguibi M, Belahsen R. Metabolic syndrome among Moroccan Sahraoui adult Women. Am J Hum Biol. 2004;16(5):598-601.

86. Sirdah MM, Al Laham NA, Abu Ghali AS. Prevalence of metabolic syndrome and associated socioeconomic and demographic factors among Palestinian adults (20-65 years) at the Gaza Strip. Diabetes Metab Syndr. 2011:5(2):93-7.

87. de Moraes ACF, Guerra PH, Menezes PR. The worldwide prevalence of insufficient physical activity in adolescents; a systematic review. Nutr Hosp. 2013;28(3):575-84. https://doi.org/10.3305/nh.2013.28.3.6398.

88. Sallis JF, Bull F, Guthold R, Heath GW, Inoue S, Kelly P, et al. Progress in physical activity over the Olympic quadrennium. The Lancet. 2016;

89. World Health Organization. Prevalence of insufficient physical activity. 2016. http://www.who.int/gho/ncd/risk_factors/physical_activity_text/en/.

90. Hallal PC, Andersen LB, Bull FC, Guthold R, Haskell W, Ekelund U, et al. Global physical activity levels: surveillance progress, pitfalls, and prospects. Lancet. 2012;380(9838):247-57.

91. Kahan D. Adult physical inactivity prevalence in the Muslim world: Analysis of 38 countries. Prev Med Rep. 2015;2:71-5. https://doi.org/10.1016/j.pmedr. 2014.12.007

92. Al Ali R, Rastam S, Fouad FM, Mzayek F, Maziak W. Modifiable cardiovascular risk factors among adults in Aleppo, Syria. Int J Public Health. 2011;56(6):653-62.

93. Bauman A, Ainsworth BE, Sallis JF, Hagstromer M, Craig CL, Bull FC, et al. The descriptive epidemiology of sitting. A 20-country comparison using the International Physical Activity Questionnaire (IPAQ). Am J Prev Med. 2011; 41(2):228-35.

94. World Health Organization. Global School-based Student Health Survey Oman 2015 Fact Sheet 2015.

95. Abdulle AM, Nagelkerke NJ, Abouchacra S, Pathan JY, Adem A, Obineche EN. Under- treatment and under diagnosis of hypertension: a serious problem in the United Arab Emirates. BMC Cardiovasc Disord. 2006;6:24.

96. Abou-Zeid AH, Hifnawy TM, Abdel Fattah M. Health habits and behaviour of adolescent schoolchildren, Taif, Saudi Arabia. East Mediterr Health J. 2009; 15(6):1525-34.

97. Al-Haifi AR, Al-Fayez MA, Al-Athari Bl, Al-Ajmi FA, Allafi AR, Al-Hazzaa HM, et al. Relative contribution of physical activity, sedentary behaviors, and dietary habits to the prevalence of obesity among Kuwaiti adolescents. Food Nutr Bull. 2013;34(1):6-13

98. Al-Hazzaa HM, Abahussain NA, Al-Sobayel HI, Qahwaji DM, Musaiger AO. Lifestyle factors associated with overweight and obesity among Saudi adolescents. Bmc Public Health. 2012;12 https://doi.org/10.1186/1471-245812-354.
99. Al-Hazzaa HM, Al-Sobayel HI, Abahussain NA, Qahwaji DM, Alahmadi MA, Musaiger AO. Association of dietary habits with levels of physical activity and screen time among adolescents living in Saudi Arabia. J Human Nut Dietetics. 2014;27(Suppl 2):204-13.

100. Al Sabbah H, Vereecken C, Kolsteren P, Abdeen Z, Maes L. Food habits and physical activity patterns among Palestinian adolescents: findings from the national study of Palestinian schoolchildren (HBSC-WBG2004). Public Health Nutr. 2007;10(7):739-46.

101. Hamrani A, Mehdad S, El Kari K, El Hamdouchi A, El Menchawy I, Belghiti H, et al. Physical activity and dietary habits among Moroccan adolescents. Public Health Nutr. 2015;18(10):1793-800

102. Donnelly T, Al Suwaidi J, Al Enazi NR, Idris Z, Albulushi AM, Yassin K, et al. Qatari Women Living With Cardiovascular Diseases-Challenges and Opportunities to Engage in Healthy Lifestyles. Health Care Women Int. 2012:33(12):1114-34

103. Samara A, Nistrup A, Al-Rammah TY, Aro AR. Lack of facilities rather than sociocultural factors as the primary barrier to physical activity among female Saudi university students. Int J Womens Health. 2015;7:279-86.

104. Pope JHG, Gruber AJ, Mangweth B, Bureau B, deCol C, Jouvent R, et al. Body image perception among men in three countries. Am J Psychiatry. 2000:157(8):1297-301. https://doi.org/10.1176/appi.ajp.157.8.1297.

105. Batnitzky A. Obesity and household roles: gender and social class in Morocco. Sociol Health IIIn. 2008;30(3):445-62. https://doi.org/10.1111/j. 1467-9566.2007.01067.x

106. Batnitzky AK. Cultural constructions of "obesity": Understanding body size, social class and gender in Morocco. Health Place. 2011;17(1):345-52.

107. Garawi F, Ploubidis GB, Devries K, Al-Hamdan N, Uauy R. Do routinely measured risk factors for obesity explain the sex gap in its prevalence? Observations from Saudi Arabia. Bmc Public Health. 2015;15. https://doi.org/ 10.1186/s12889-015-1608-6.

108. Trainer SS. Body image, health, and modernity: Women's perspectives and experiences in the United Arab Emirates. Asia Pac J Public Health. 2010; 22(3_suppl):60S-75.

109. Devi S. Jumping cultural hurdles to keep fit in the Middle East. Lancet. 2016; 388(10051):1267.

110. ParticipACTION. It's time for Canada to sit less and move more. 2016. https://www.participaction.com/. Accessed Mar 2017.

111. World Health Organization Regional Office for the Eastern Mediterranean. Promoting physical activity in the Eastern Mediterranean Region through a life-course approach.2014.

112. World Health Organization Regional Office for the Eastern Mediterranean. The Nizwa healthy lifestyles project, Oman. In: Physical activity - Case studies 2016. http://www.emro.who.int/health-education/physical-activitycase-studies/the-nizwa-healthy-lifestyles-project-oman.html. Accessed Aug 2016

113. Harrabi I, Maatoug J, Gaha M, Kebaili R, Gaha R, Ghannem H. School-based Intervention to Promote Healthy Lifestyles in Sousse, Tunisia. Indian J Community Med. 2010;35(1):94-9. https://doi.org/10.4103/0970-0218.62581.

114. Habib-Mourad C, Ghandour LA, Moore HJ, Nabhani-Zeidan M, Adetayo K, Hwalla N, et al. Promoting healthy eating and physical activity among school children: findings from Health-E-PALS, the first pilot intervention from Lebanon. Bmc Public Health. 2014;14 https://doi.org/10.1186/1471-2458-14-940.

115. Gardner B, Smith L, Lorencatto F, Hamer M, Biddle SJ. How to reduce sitting time? A review of behaviour change strategies used in sedentary behaviour reduction interventions among adults. Health Psychol Rev. 2016;10(1):89-112.

116. World Health Organization. Algeria STEPS Survey 2003 Fact Sheet 2003.

117. World Health Organization. Global School-based Student Health Survey Algeria 2011 Fact Sheet 2011.

118. Abbes MA, Bereksi-Reguig K. Risk factors for obesity among school aged children in western Algeria: results of a study conducted on 293 subjects. Tunis Med. 2016:94(1):23-8.

119. World Health Organization. Report of the National Non-communicable Diseases Step-wise Survey 2007.

120. Al-Mahroos F, Al-Roomi K. Obesity among adult Bahraini population: Impact of physical activity and educational level. Ann Saudi Med. 2001;21(3-4):183-7.

121. Hamadeh RR, Musaiger AO. Lifestyle patterns in smokers and non-smokers in the state of Bahrain. Nicotine Tob Res. 2000;2(1):65-9.

122. Borgan SM, Jassim GA, Marhoon ZA, Ibrahim MH. The lifestyle habits and wellbeing of physicians in Bahrain: a cross-sectional study. BMC Public Health. 2015;15:655. 
123. World Health Organization. STEPS 2011 Note de synthèse 2011.

124. World Health Organization. Global School-based Student Health Survey Djibouti 2007 Fact Sheet 2007.

125. World Health Organization. Egypt STEPS Survey 2011-12 2012.

126. World Health Organization. Global School-based Student Health Survey Egypt 2011 Fact Sheet 2011.

127. El Ansari W, Stock C. Relationship between attainment of recommended physical activity guidelines and academic achievement: undergraduate students in Egypt. Glob J Health Sci. 2014;6(5):274-83.

128. Kamel MH, Abdulmajeed AA, Ismail Sel S. Risk factors of falls among elderly living in urban Suez-Egypt. Pan Afr Med J. 2013;14:26.

129. Mahfouz EM, Sadek RR, Abdel-Latief WM, Mosallem FA, Hassan EE. The role of dietary and lifestyle factors in the development of colorectal cancer: case control study in Minia, Egypt. Cent Eur J Public Health. 2014:22(4):215-22.

130. Shady MM, Youssef MM, Shehata MA, El-Din EM, ElMalt HA. Association of Serum 25-Hydroxyvitamin D with Life Style and Dietary Factors in Egyptian Prepubescent Children. Open Access Maced J Med Sci. 2015; 3(1):80-4.

131. Peltzer K, Pengpid S. Correlates of healthy fruit and vegetable diet in students in low, middle and high income countries. Int J Public Health. 2015;60(1):79-90. https://doi.org/10.1007/s00038-014-0631-1.

132. Shaeer KZ, Osegbe DN, Siddiqui SH, Razzaque A, Glasser DB, Jaquste V. Prevalence of erectile dysfunction and its correlates among men attending primary care clinics in three countries: Pakistan, Egypt, and Nigeria. Int J Impot Res. 2003;15(Suppl 1):S8-14.

133. World Health Organization. Noncommunicable Diseases Risk Factors STEPS survey Iraq 2015.

134. World Health Organization. Global School-based Student Health Survey Iraq 2012 Fact Sheet 2012.

135. Al-Tawil NG, Abdulla MM, Abdul Ameer AJ. Prevalence of and factors associated with overweight and obesity among a group of Iraqi women. East Mediterr Health J. 2007;13(2):420-9.

136. World Health Organization. Jordan STEPS Survey 2007 Fact Sheet 2007.

137. World Health Organization. Global School-based Student Health Survey Jordan 2007 Fact Sheet 2007

138. Ghalayini IF, Al-Ghazo MA, Al-Azab R, Bani-Hani I, Matani YS, Barham AE, et al. Erectile dysfunction in a Mediterranean country: results of an epidemiological survey of a representative sample of men. Int J Impot Res. 2010;22(3):196-203.

139. Khader $Y$, Irshaidat $O$, Khasawneh M, Amarin Z, Alomari M, Batieha A. Overweight and Obesity Among School Children in Jordan: Prevalence and Associated Factors. Matern Child Health J. 2009;13(3):424-31. https://doi.org/ 10.1007/s10995-008-0362-0.

140. Tayyem RF, Al-Hazzaa HM, Abu-Mweis SS, Bawadi HA, Hammad SS, Musaiger AO. Dietary habits and physical activity levels in Jordanian adolescents attending private versus public schools. East Mediterr Health J. 2014;20(7):416-23.

141. Zindah M, Belbeisi A, Walke $H$, Mokdad AH. Obesity and diabetes in Jordan: findings from the behavioral risk factor surveillance system, 2004. Prev Chronic Dis. 2008;5(1):A17.

142. Kulwicki AD, Kepler C. Assessment of cardiovascular risk factors among residents of a city in Jordan. J Cult Divers. 2001;8(2):34-40.

143. Centers for Disease C, Prevention. Prevalence of selected risk factors for chronic disease-Jordan, 2002. MMWR Morb Mortal Wkly Rep. 2003;52(43): 1042-4

144. World Health Organization. WHO STEPwise Approach to NCD Surveillance Country-Specific Standard Report 2005.

145. Al-Muammar MN, El-Shafie M, Feroze S. Association between dietary habits and body mass index of adolescent females in intermediate schools in Riyadh, Saudi Arabia. East Mediterr Health J. 2014;20(1):39-45.

146. Almurshed KS. Colorectal cancer: case-control study of sociodemographic, lifestyle and anthropometric parameters in Riyadh. East Mediterr Health J. 2009;15(4):817-26.

147. Al-Othman A, Al-Musharaf S, Al-Daghri NM, Krishnaswamy S, Yusuf DS, Alkharfy KM, et al. Effect of physical activity and sun exposure on vitamin D status of Saudi children and adolescents. BMC Pediatrics. 2012;12:92.

148. AlQuaiz AM, Kazi A, Tayel S, Shaikh SA, Al-Sharif A, Othman S, et al. Prevalence and factors associated with low bone mineral density in Saudi women: a community based survey. BMC Musculoskelet Disord. 2014;15:5.

149. Alquaiz JM, Siddiqui AR, Tayel SA, Habib FA. Determinants of severity of menopausal symptoms among Saudi women in Riyadh city. Climacteric. 2014;17(1):71-8.
150. Amin T, Al-Hammam AM, AlMulhim NA, Al-Hayan Ml, Al-Mulhim MM, AlMosabeh MJ, et al. Physical activity and cancer prevention: awareness and meeting the recommendations among adult Saudis. Asian Pac J Cancer Prev. 2014;15(6):2597-606.

151. Ardawi MS, Sibiany AM, Bakhsh TM, Qari MH, Maimani AA. High prevalence of vitamin D deficiency among healthy Saudi Arabian men: relationship to bone mineral density, parathyroid hormone, bone turnover markers, and lifestyle factors. Osteoporos Int. 2012;23(2):675-86.

152. Balaha MH, Amr MA, Saleh Al Moghannum M, Saab Al Muhaidab N. The phenomenology of premenstrual syndrome in female medical students: a cross sectional study. Pan Afr Med J. 2010;5:4.

153. Collison KS, Zaidi MZ, Subhani SN, Al-Rubeaan K, Shoukri M, Al-Mohanna FA Sugar-sweetened carbonated beverage consumption correlates with BMl, waist circumference, and poor dietary choices in school children. BMC Public Health. 2010;10:234

154. Farghaly NE, Ghazali BM, Al-Wabel HM, Sadek AA, Abbag Fl. Life style and nutrition and their impact on health of Saudi school students in Abha, Southwestern region of Saudi Arabia. Saudi Med J. 2007;28(3):415-21.

155. Khalaf A, Westergren A, Berggren V, Ekblom O, Al-Hazzaa HM. Prevalence and association of female weight status and dietary habits with sociodemographic factors: a cross-sectional study in Saudi Arabia. Public Health Nutr. 2015;18(5):784-96. https://doi.org/10.1017/s1368980014001797.

156. Koura MR, Al-Dabal BK, Rasheed P, Al-Sowielem LS, Makki SM. Prehypertension among young adult females in Dammam, Saudi Arabia. East Mediterr Health J. 2012;18(7):728-34.

157. Memish ZA, El Bcheraoui C, Tuffaha M, Robinson M, Daoud F, Jaber S, et al. Obesity and associated factors-Kingdom of Saudi Arabia, 2013. Prev Chronic Dis. 2014;11:E174.

158. Rasheed P, Al-Sowielem LS. Prevalence and predictors of premenstrual syndrome among college-aged women in Saudi Arabia. Ann Saudi Med. 2003;23(6):381-7.

159. Sabra AA, Taha AZ, Al-Sebiany AM, Al-Kurashi NY, Al-Zubier AG. Coronary heart disease risk factors: prevalence and behavior among male university students in Dammam City, Saudi Arabia. J Egypt Public Health Assoc. 2007:82(1-2):21-42.

160. Khalid ME. The prevalence of abdominal obesity and its associated risk factors in married, non-pregnant women born and living in high altitude, southwestern Saudi Arabia. Saudi Med J. 2007:28(12):1875-80.

161. Alissa EM, Bahjri SM, Al-Ama N, Ahmed WH, Ferns GA. High cardiovascular risk in young Saudi males: cardiovascular risk factors, diet and inflammatory markers. Clin Chim Acta. 2006;365(1-2):288-96.

162. Al-Rukban MO. Obesity among Saudi male adolescents in Riyadh, Saudi Arabia. Saudi Med J. 2003;24(1):27-33.

163. Al Senany S, Al Saif A. Assessment of physical health status and quality of life among Saudi older adults. J Phys Ther Sci. 2015;27(6):1691-5.

164. Al-Marwani Al-Juhani M, Khandekar R, Al-Harby M, Al-Hassan A, Edward DP. Neck and upper back pain among eye care professionals. Occup Med (Lond). 2015;65(9):753-7.

165. Al-Muhaimeed AA, Dandash K, Ismail MS, Saquib N. Prevalence and correlates of overweight status among Saudi school children. Ann Saudi Med. 2015;35(4):275-81.

166. Banday AH, Want FA, Alris FF, Alrayes MF, Alenzi MJ. A Cross-sectional Study on the Prevalence of Physical Activity Among Primary Health Care Physicians in Aljouf Region of Saudi Arabia. Mater Sociomed. 2015;27(4):263-6.

167. AlBuhairan FS, Tamim H, Al Dubayee M, AlDhukair S, Al Shehri S, Tamimi W, et al. Time for an Adolescent Health Surveillance System in Saudi Arabia: Findings From "Jeeluna". J Adolesc Health. 2015;57(3):263-9. https://doi.org/ 10.1016/j.jadohealth.2015.06.009.

168. World Health Organization. EMAN Eastern Mediterranean Approach for Control of Non Communicable Diseases Survey of Risk Factors for Chronic Non Communicable Diseases State of Kuwait 2015

169. Ahmed F, Waslien C, Al-Sumaie MA, Prakash P. Secular trends and risk factors of overweight and obesity among Kuwaiti adults: National Nutrition Surveillance System data from 1998 to 2009. Public Health Nutr. 2012;15(11):2124-30

170. Al Zenki S, Al Omirah H, Al Hooti S, Al Hamad N, Jackson RT, Rao A, et al. High prevalence of metabolic syndrome among Kuwaiti adults-a wake-up call for public health intervention. Int J Environ Res Public Health. 2012;9(5):1984-96.

171. Alarouj M, Bennakhi A, Alnesef Y, Sharifi M, Elkum N. Diabetes and associated cardiovascular risk factors in the State of Kuwait: the first national survey. Int J Clin Pract. 2013;67(1):89-96. 
172. Allafi AR, Waslien C. Association of Unhealthy Exercise Patterns with Overweigh and Obesity in Kuwaiti Adults. Iran J Public Health. 2014;43(11):1497-502.

173. Alrowayeh HN, Alshatti TA, Aljadi SH, Fares M, Alshamire MM, Alwazan SS. Prevalence, characteristics, and impacts of work-related musculoskeletal disorders: a survey among physical therapists in the State of Kuwait. BMC Musculoskelet Disord. 2010;11:116.

174. Alyahya K, Lee WT, Al-Mazidi Z, Morgan J, Lanham-New S. Risk factors of low vitamin D status in adolescent females in Kuwait: implications for high peak bone mass attainment. Arch Osteoporos. 2014;9:178.

175. Shehab DK, Al-Jarallah KF. Nonspecific low-back pain in Kuwaiti children and adolescents: associated factors. J Adolesc Health. 2005;36(1):32-5.

176. Al-Kandari YY. Prevalence of obesity in Kuwait and its relation to sociocultural variables. Obes Rev. 2006;7(2):147-54

177. Ahmed F, Waslien C, Al-Sumaie MA, Prakash P, Allafi A. Trends and risk factors of hyperglycemia and diabetes among Kuwaiti adults: National Nutrition Surveillance Data from 2002 to 2009. BMC Public Health. 2013;13:103.

178. Sibai AM, Hwalla N. WHO STEPS Chronic Disease Risk Factor Surveillance: World Health Organization 2010.

179. World Health Organization. Global School-based Student Health Survey Lebanon 2011 Fact Sheet 2011.

180. Arevian M, Adra M, Kubeissi L. Risk factors for coronary artery disease (CAD) in Lebanese-Armenian women. Health Care Women Int. 2004; 25(10):933-49.

181. Chamieh MC, Moore HJ, Summerbell C, Tamim H, Sibai AM, Hwalla N. Diet, physical activity and socio-economic disparities of obesity in Lebanese adults: findings from a national study. Bmc Public Health. 2015;15. https://doi.org/10.1186/s12889-015-1605-9.

182. Costanian C, Bennett K, Hwalla N, Assaad S, Sibai AM. Prevalence, correlates and management of type 2 diabetes mellitus in Lebanon: findings from a national population-based study. Diabetes Res Clin Pract. 2014;105(3):408-15.

183. Nasreddine L, Naja F, Akl C, Chamieh MC, Karam S, Sibai AM, et al. Dietary, lifestyle and socio-economic correlates of overweight, obesity and central adiposity in Lebanese children and adolescents. Nutrients. 2014;6(3):1038-62.

184. Tamim H, Terro A, Kassem H, Ghazi A, Abou Khamis T, Hay MMA, et al. Tobacco use by university students, Lebanon, 2001. Addiction. 2003;98(7): 933-9. https://doi.org/10.1046/j.1360-0443.2003.00413.x.

185. Tohme RA, Jurjus AR, Estephan A. The prevalence of hypertension and its association with other cardiovascular disease risk factors in a representative sample of the Lebanese population. J Hum Hypertens. 2005;19(11):861-8.

186. Farah R, Zeidan RK, Chahine MN, Asmar R, Chahine R, Salameh P, et al. Prevalence of stroke symptoms among stroke-free residents: first national data from Lebanon. Int J Stroke. 2015;10 Suppl. A100:83-8.

187. World Health Organization. Libya STEPS Survey 2009 Fact Sheet 2009.

188. World Health Organization. Global School-based Student Health Survey Libya 2007 Fact Sheet 2007.

189. Salam AA, Alshekteria AA, Mohammed HA, Al Abar NM, Al Jhany MM, Al Flah F. Physical, mental, emotional and social health status of adolescents and youths in Benghazi, Libya. East Mediterr Health J. 2012;18(6):586-97.

190. Lamine M, Pathé D. Enquête sur les Maladies non Transmissibles selon l'approche STEPwise de l'OMS : étude de l'hypertension arterielle, du diabete et des autres facteurs de risque a Nouakchott Mauritanie Janvierjuin 2006 World Health Organization 2007.

191. World Health Organization. Global School-based Student Health Survey Mauritania 2010 Fact Sheet 2010

192. World Health Organization. Global School-based Student Health Survey Morocco 2010 Fact Sheet 2010

193. El Maghraoui A, Ghazi M, Gassim S, Ghozlani I, Mounach A, Rezqi A, et al. Risk factors of osteoporosis in healthy Moroccan men. BMC Musculoskelet Disord. 2010;11:148.

194. Al Farsi M, El Melighy M, Mohamed S, Ali L. Assessment of life style risk factors among sur city population: World Health Organization 2006.

195. Afifi M. Positive health practices and depressive symptoms among high school adolescents in Oman. Singapore Med J. 2006;47(11):960-6.

196. Albarwani S, Al-Hashmi K, Al-Abri M, Jaju D, Hassan MO. Effects of Overweight and Leisure-Time Activities on Aerobic Fitness in Urban and Rural Adolescents. Metab Syndr Relat Disord. 2009;7(4):369-73. https://doi.org/10.1089/met.2008.0052

197. Khoo S, Al-Shamli AK. Leisure-Time Physical Activity and Physical Fitness of Male Adolescents in Oman. Asia Pac J Public Health. 2012;24(1):128-35. https://doi.org/10.1177/1010539510366178.
198. Li C, Zayed K, Muazzam A, Li MY, Cheng J, Chen AN. Motives for Exercise in Undergraduate Muslim Women and Men in Oman and Pakistan Compared to the United States. Sex Roles. 2015;72(1-2):68-84. https://doi.org/10.1007/ s11199-014-0435-z.

199. World Health Organization. Global School-based Student Health Survey oPt Gaza 2010 Fact Sheet 2010.

200. World Health Organization. Global School-based Student Health Survey oPt West Bank 2010 Fact Sheet 2010.

201. Abu-Mourad T, Alegakis A, Shashaa S, Koutis A, Lionis C, Philalithis A. Individual determinants of primary healthcare utilisation in Gaza Strip, Palestine. J Epidemiol Community Health. 2008;62(8):701-7.

202. Baron-Epel O, Haviv A, Garty N, Tamir D, Green MS. Who are the sedentary people in Israel? A public health indicator. Isr Med Assoc J. 2005;7(11):694-9.

203. Jildeh C, Papandreou C, Abu Mourad T, Hatzis C, Kafatos A, Qasrawi R, et al. Assessing the nutritional status of Palestinian adolescents from East Jerusalem: a school-based study 2002-03. J Trop Pediatr. 2011;57(1):51-8.

204. Merom D, Sinnreich R, Aboudi V, Kark JD, Nassar H. Lifestyle physical activity among urban Palestinians and Israelis: a cross-sectional comparison in the Palestinian-Israeli Jerusalem risk factor study. BMC Public Health. 2012;12:90.

205. World Health Organization. Qatar STEPS Survey 2012 Fact Sheet 2012.

206. World Health Organization. Global School-based Student Health Survey Qatar 2011 Fact Sheet 2011.

207. Bener A, Al-Ali M, Hoffmann GF. Vitamin D deficiency in healthy children in a sunny country: associated factors. Int J Food Sci Nutr. 2009;60(Suppl 5):60-70.

208. Bener A, Alsaied A, Al-Ali M, Al-Kubaisi A, Basha B, Abraham A, et al. High prevalence of vitamin $D$ deficiency in type 1 diabetes mellitus and healthy children. Acta Diabetol. 2009;46(3):183-9.

209. Bener A, Alsaied A, Al-Ali M, Hassan AS, Basha B, Al-Kubaisi A, et al. Impact of lifestyle and dietary habits on hypovitaminosis $D$ in type 1 diabetes mellitus and healthy children from Qatar, a sun-rich country. Ann Nutr Metab. 2008;53(3-4):215-22.

210. Bener A, Al-Suwaidi J, Al-Jaber K, Al-Marri S, Dagash MH, Elbagi IE. The prevalence of hypertension and its associated risk factors in a newly developed country. Saudi Med J. 2004;25(7):918-22.

211. Bener A, Bhugra D. Lifestyle and depressive risk factors associated with problematic internet use in adolescents in an Arabian Gulf culture. J Addict Med. 2013;7(4):236-42.

212. Bener A, Moore MA, Ali R, El Ayoubi HR. Impacts of family history and lifestyle habits on colorectal cancer risk: a case-control study in Qatar. Asian Pac J Cancer Prev. 2010;11(4):963-8.

213. Bener A, Zirie M, Al-Rikabi A. Genetics, obesity, and environmental risk factors associated with type 2 diabetes. Croat Med J. 2005:46(2):302-7.

214. Al Thani M, Al Thani AA, Al-Chetachi W, Al Malki B, Khalifa SA, Bakri AH, et al. Lifestyle Patterns Are Associated with Elevated Blood Pressure among Qatari Women of Reproductive Age: A Cross-Sectional National Study. Nutrients. 2015;7(9):7593-615.

215. Ali M, Yusuf HI, Stahmer J, Rahlenbeck SI. Cardiovascular Risk Factors and Physical Activity Among University Students in Somaliland. J Community Health. 2015:40(2):326-30. https://doi.org/10.1007/s10900-014-9938-3.

216. World Health Organization. Khartoum State/ Sudan STEPS Survey 2005-2006 factsheet 2006

217. World Health Organization. Global School-based Student Health Survey Sudan 2012 Fact Sheet 2012

218. Moukhyer ME, van Eijk JT, De Vries NK, Bosma H. Health-related behaviors of Sudanese adolescents. Educ Health. 2008;21(1):184.

219. World Health Organization. Global School-based Student Health Survey Syria 2010 Fact Sheet 2010.

220. Albache N, Al Ali R, Rastam S, Fouad FM, Mzayek F, Maziak W. Epidemiology of Type 2 diabetes mellitus in Aleppo, Syria. J Diabetes. 2010;2(2):85-91.

221. Fouad MF, Rastam S, Ward KD, Maziak W. Prevalence of obesity and its associated factors in Aleppo, Syria. Prev Control. 2006;2(2):85-94. https://doi.org/10.1016/j.precon.2006.09.001.

222. World Health Organization. Global School-based Student Health Survey Tunisia 2008 Fact Sheet 2008.

223. Aounallah-Skhiri H, El Ati J, Traissac P, Ben Romdhane H, Eymard-Duvernay $S$, Delpeuch F, et al. Blood pressure and associated factors in a North African adolescent population. a national cross-sectional study in Tunisia. BMC Public Health. 2012;12:98 
224. Aounallah-Skhiri H, Traissac P, El Ati J, Eymard-Duvernay S, Landais E, Achour N, et al. Nutrition transition among adolescents of a south-Mediterranean country: dietary patterns, association with socio-economic factors, overweight and blood pressure. A cross-sectional study in Tunisia. Nutr J. 2011:10:38.

225. Nouira A, Maatoug J, Harrabi I, Hmad S, Belkacem M, Slama S, et al. Clustering of risk factors in the smoking habits of schoolchildren in Sousse, Tunisia. Int J Adolesc Med Health. 2014;26(2):267-73. https://doi.org/10. 1515/ijamh-2013-0511.

226. Abdelkafi Koubaa A, Younes K, Gabsi Z, Bouslah A, Maalel I, Maatouk El May W, et al. Risk factors of children overweight and obesity. Tunisie Medicale. 2012;90(5):387-93.

227. Ben Saad H, Tfifha M, Harrabi I, Tabka Z, Guenard H, Hayot M, et al. Factors influencing pulmonary function in Tunisian women aged 45 years and more. Rev Mal Respir. 2006;23(4 Pt 1):324-38.

228. Regaieg S, Charfi N, Elleuch M, Mnif F, Marrakchi R, Yaich S, et al. Obesity, physical activity and sedentary time among school adolescents aged 15 to 18 years in the city of Sfax (Tunisia). Pan Afr Med J. 2015;22:370.

229. World Health Organization. Global School-based Student Health Survey United Arab Emirates 2010 Fact Sheet 2010.

230. Barakat-Haddad C. Prevalence of high blood pressure, heart disease, thalassemia, sickle-cell anemia, and iron-deficiency anemia among the UAE adolescent population. J Environ Public Health. 2013;2013:680631.

231. Carter AO, Saadi HF, Reed RL, Dunn EV. Assessment of obesity, lifestyle, and reproductive health needs of female citizens of Al Ain, United Arab Emirates. J Health Popul Nutr. 2004;22(1):75-83.

232. Sabri S, Bener A, Eapen V, Abu Zeid MS, Al-Mazrouei AM, Singh J. Some risk factors for hypertension in the United Arab Emirates. East Mediterr Health J. 2004;10(4-5):610-9.

233. Mcllvenny S, DeGlume AM, Elewa M, Fernandez OT, Dormer P. Factors associated with fatigue in a Family Medicine clinic in the United Arab Emirates. Family Prac. 2000;17(5):408-13. https:/doi.org/10.1093/fampra/17.5.408.

234. World Health Organization. Global School-based Student Health Survey Yemen 2008 Fact Sheet 2008

\section{Ready to submit your research? Choose BMC and benefit from:}

- fast, convenient online submission

- thorough peer review by experienced researchers in your field

- rapid publication on acceptance

- support for research data, including large and complex data types

- gold Open Access which fosters wider collaboration and increased citations

- maximum visibility for your research: over $100 \mathrm{M}$ website views per year

At BMC, research is always in progress.

Learn more biomedcentral.com/submissions 